International Journal of Public Finance
E-ISSN: $2548-0499 \quad$ DOI: $10.30927 /$ ijpf.319901
Vol./Cilt: 1 | Issue/Sayı: 2 | (2016), pp. $194-219$
journal homepage: http://dergipark.gov.tr/ijpf

\title{
Taşınmazların Elden Çıkarılmasında Elde Edilen Kazançların Vergilendirilmesi: Yeni Gelir Vergisi Kanun Tasarısının Getirdikleri*
}

\author{
Taxation of Income from Selling Property: Changes of New \\ Income Tax Law Draft
}

Canatay HACIKÖYLÜ ${ }^{1}$

\begin{abstract}
ARTICLE INFO
Received: 17.01.2016

Received in revised form: 30.03.2016

Accepted: 11.04.2016

Available online:

26.12.2016

JEL classification:

$\mathrm{H} 20, \mathrm{H} 24, \mathrm{H} 27$

\section{Keywords:}

The Income Tax Law

Draft, Property,

Capital Gains, Rant
\end{abstract}

\begin{abstract}
A B S T R A C T
There are provisions in Income Tax Law No. 193 and Corporate Tax Law No. 5520 on the nature and taxation of income that real and legal persons acquire from real estate sales. There have been many changes in these provisions over time, but the changes made didnt meet the needs, and they distorted the systematic structure of the Laws. For these and similar reasons, the income tax law draft has been prepared based on Income Tax Law and Corporate Tax Law. With the draft, the Income Tax Law No. 193 and the Corporate Tax Law No. 5520 will be abolished. Draft is aimed to regulate the procedures and principles regarding the income tax on the income of real persons and institutions. In this study, the current situation and the regulations of the draft will be discussed. Moreover, It will be evaluate whether the regulations in the draft law are sufficient. Suggestions will be put forth to determine and declare the real value of the property in order to achieve the intended objectives in draft.
\end{abstract}

\section{MAKALE Bílgisi}

Alındı: 17.01.2016 Gözden geçirilmiş alındı: 30.03 .2016

Kabul: 11.04.2016

Yayın: 26.12.2016

\section{JEL Kodu:}

$\mathrm{H} 20, \mathrm{H} 24, \mathrm{H} 27$

Anahtar Kelimeler:

\section{Ö ZE T}

Gerçek ve tüzel kişilerin taşınmaz satışından elde ettikleri gelirin niteliği ve vergilendirilmesi hakkında 193 sayılı Gelir Vergisi Kanununda ve 5520 sayılı Kurumlar Vergisi Kanununda hükümler bulunmaktadır. Bu hükümlerde zamanla birçok değişiklik yapılmış ancak yapılan değişiklikler ihtiyaçları karşılamadığı gibi anılan Kanunların sistematik yapısını da bozmuştur. Bu ve benzeri nedenlerden dolayı gelir üzerinden alınan vergileri düzenleyen Gelir Vergisi Kanunu ve Kurumlar Vergisi Kanunlarının birlikte bir bütünlük içinde ele alınarak Gelir Vergisi Kanunu tasarısı hazırlanmıştır. Tasarı ile 193 sayılı

15-19 Mayıs 2016 tarihleri arasında düzenlenen 31. Türkiye Maliye Sempozyumu'nda sunulan metnin gözden geçirilmiş ve düzeltilmiş hâlidir.

1 Yrd. Doç. Dr. Anadolu Üniversitesi, ỉktisat Fakültesi, Maliye Bölümü, chacikoylu@anadolu.edu.tr 
Gelir Vergisi Kanunu Tasarısı, Taşınmaz, Değer Artış Kazancı, Rant
Gelir Vergisi Kanunu ve 5520 sayılı Kurumlar Vergisi Kanunu yürürlükten kaldırılarak, gerçek kişilerin ve kurumların gelirleri üzerinden alınan gelir vergisine ilişkin usul ve esasların düzenlenmesi amaçlanmaktadır. Bu çalışmada mevcut durum ve tasarıda öngörülen düzenlemeler ele alınacaktır. Ayrıca tasarıda öngörülen düzenlemelerin yeterli olup olmadığı değerlendirilecek, gerekçede hedeflenen amaçlara ulaşılabilmesi için taşınmazların gerçek değerinin tespitine ve beyanına yönelik öneriler getirilecektir.

\section{Giriş}

Taşınmazların elden çıkarılmasında elde edilen gelirler, geliri elde eden kişi ya da kuruma göre değişiklik göstermektedir. 193 sayılı Gelir Vergisi Kanununda gerçek kişilerin taşınmaz satışından elde ettikleri gelirin niteliği ve vergilendirilmesi hakkında iki ayrı gelir (kazanç) türünde düzenlemelere yer verilmiştir. Bunlardan ilki Kanununun "Ticari Kazanç" başlığını taşıyan 37. maddesinin 4. fıkrasındaki "taşınmazların alımsatım ve inşa işleriyle devamlı olarak uğraşanların bu işlerden elde ettikleri kazançların" ticari kazanç olarak vergilendirileceğine ilişkin hükümdür. Diğeri ise anılan Kanunun diğer kazanç ve iratlara ilişkin "değer artış kazançları" başlığını taşıyan mükerrer 80. maddesinde yer alan ve taşınmaz alım-satımında ticari kazanç olmaksızın şahsi ihtiyacın karşılanması ve servetin korunması amacıyla yapılan satışlardan elde edilen kazanca ilişkin vergisel yükümlülüklere ilişkin hükümdür.

Bununla birlikte, 5520 sayılı Kurumlar Vergisi Kanununda taşınmaz ticareti ve kiralanmasıyla uğraşan kurumların bu amaçla ellerinde bulundurdukları taşınmazların satışından elde ettikleri gelirler hariç olmak üzere taşınmaz satış kazançlarına yönelik Kanunun 5. maddesinin (1) fıkrasının (e) bendinde bir istisna getirilmiştir.

Mevcut mevzuatımızda yer alan 193 sayılı Gelir Vergisi Kanunu 01.01.1961 tarihinde yürürlüğe giren, gerçek kişilerin elde ettikleri gelirlerin (kazanç ve iratların) vergilendirilmesini esas alan ve yaklaşık 55 yıldır uygulanan bir kanundur. Gelir Vergisi Kanununun ekonomideki gelişmelere ve değişimlere daha uygun hale getirilebilmesi için zamanla yeni düzenlemeler yapılmış; ancak yapılan değişiklikler bir bütünlük arz etmediğinden, sistematik yapı bozulmuş, Kanun; basit, sade ve kolay anlaşılabilir olmaktan uzaklaşmıştır. Ayrıca yapılan bu değişiklikler ve eklemeler sonucu, kanunun madde sayısı 210'nu aşmıştır. Mevcut Gelir Vergisi Kanununda bazı temel düzenlemelere geçici maddeler ile yön veriliyor olması da öngörülebilirliği azaltan bir unsur olmuştur.

$\mathrm{Bu}$ ve benzeri nedenlerden dolayı gelir üzerinden alınan vergileri düzenleyen Gelir Vergisi Kanunu ve Kurumlar Vergisi Kanunlarının birlikte bir bütünlük içinde ele alınarak Gelir Vergisi Kanunu tasarısı hazırlanmıştır. Tasarı ile 193 sayılı Gelir Vergisi Kanunu ve 5520 sayılı Kurumlar Vergisi Kanunu yürürlükten kaldırılarak, gerçek kişilerin gelirleri ile kurumların kazançları üzerinden alınan gelir vergisine ilişkin usul ve esasların düzenlenmesi amaçlanmaktadır. Hazırlanan tasarının genel gerekçesinde amaçlanan unsurlardan biri olan "vergi tabanının genişletilmesi ve vergi adaletinin pekiştirilmesi" ilkesi gereği; Kentsel rantların ve sermaye kazançlarının vergilendirilmesindeki istisnaların daraltıldığı ifade edilmektedir. Buna göre gerekçede 
"tașınmazlar, pay senetleri, ortaklık hakları ve hisselerin elden çıkarılmasından sağlanan kazançlar elde tutulma süresine göre kademeli olarak istisnaya tabi tutularak vergilendirilecektir." ifadesi yer almaktadır.

Taşınmaz değerlerinin çeşitli nedenlerle ani ve hızlı olarak artmasının yanı sıra, bunların şahıslarca işletilmesi, kiraya verilmesi ve sair şekillerde değerlendirilmesi birer rant kaynağı olarak görülebilir ve ele alınabilir. Bundan dolayı gerek taşınmazlardaki değer artışının, gerekse bunlar üzerinden elde edilen kira vb. gelirlerin vergilendirilmesi ve bu suretle bunlardan elde edilen rantların bir kısmının kamuya aktarılması tasarının genel gerekçesinde de ifade edildiği üzere bir zorunluluk olarak ortaya çıkmaktadır. Diğer yandan taşınmazlar, ülkemizde servet edinme veya edinilmiş servet değerinin korunmasında kullanılan araçlardan biri haline gelmişlerdir ve genellikle üst gelir gruplarının başvurduğu bir yatırım aracı olarak kullanılmaktadırlar. Dolayısıyla bu şekilde oluşan servetlerin vergilendirilmesi alt gelir gruplarında ortaya çıkabilecek hoşnutsuzlukları da hafifletebilecektir. Bu nedenle taşınmazlar üzerinden elde edilen bu rantların kamuya aktarılarak, kamunun gereken payı almasını sağlamak zorunluluk halini almıştır. (GVK Tasarısı, Genel Gerekçe, http://www2.tbmm.gov.tr/d26/1/10516.pdf)

Bu konunun tasarıda zorunluluk olarak ifade edilmesinin nedenlerinden birinin de mevcut düzenlemeler çerçevesinde ne gelir vergisi (değer artış kazançları açısından) ne de ilgili diğer kanunlarda taşınmaz değer artışlarının kamuya aktarılmasında etkin bir düzenleme ve kontrol mekanizmasının olmamasıdır. Bu çalışmada tasarı ile bu mekanizmanın oluşturulup oluşturulamayacağı da tartışılacaktır.

\section{Taşınmaz ve Rant Kavramları}

Çalışmada gayrimenkul kavramı yerine taşınmaz kavramı kullanılmıştır. 2000'li yılların başından itibaren yapılan yasal düzenlemelerde kullanılan dil oldukça Türkçeleştirilmeye çalışılmış, günümüzde geçerli olan dile oranla eskimiş olan ifadeler kolay anlaşılabilir ifadelere dönüştürülmüş ve düzenlemelerin genelinde terim birliğinin sağlanmasına yönelik büyük çaba harcanmıştır. Bu çerçevede birçok kavram ve terim günümüzde yerleşmiş olan yeni karşılıkları ile değiştirilmektedir. Değiştirilen kavramlardan biri de gayrimenkul kavramıdır. 2000'li yılların başından itibaren başlayan sadeleştirme ve Türkçeleştirme çabaları çalışmamızın konusunu oluşturan Gelir Vergisi Kanunu Tasarısında da görülmektedir. Tasarıda gayrimenkul kavramı yerine genellikle taşınmaz kavramının kullanılmıştır. Genellikle diyoruz çünkü her ne kadar Türkçeleştirme, terim birliği sağlama ve sadeleştirme çabaları olsa da "gayrimenkul sermaye iradı" gibi bazı kavramların eski ifadeleri ile kullanılmaya devam edildiği bir gerçektir. Öyle ki 193 sayılı Gelir Vergisi Kanununun yetmiş beş farklı yerinde "gayrimenkul" kelimesi sadece dört farklı yerinde "taşınmaz" kelimesi kullanılmıştır. Buna karşın Tasarıda sadece gayrimenkul sermeye iratlarına ilişkin maddelerde "gayrimenkul" kelimesi kullanılmış bu maddeler dışında tasarının genelinde "taşınmaz" kelimesi kullanılmıştır.

Taşınmaz, fiziksel bir varlık olan arazi (arsa) ve bu arazi (arsa) üzerine insanlar tarafından yapılmış yapılar olarak tanımlanır. Taşınmaz, yerin üzerindeki veya altındaki 
tüm ilaveleri ile birlikte görülebilen, dokunulabilen maddi bir "şey" dir. (SPK,2016)Türk Medeni Kanununun 704. maddesinde taşınmaz mülkiyetinin konusu üç kategoride ifade edilmiştir. Bunlar arazi, taşınmazlar üzerindeki bağımsız ve sürekli haklar ve kat mülkiyetine konu olan bağımsız bölümlerdir.

Arazi, sınırları tabii veya suni işaretlerle belirtilmiş olan yeryüzü parçasıdır.

Tapu kütüğüne ayrı sayfada kaydedilen bağımsız ve sürekli haklar, Medeni Kanunda taşınmaz kabul edilmiştir. Fakat bir şeyin (eşyanın) taşınır-taşınmaz ayrımında kullanılan ölçüt olan hak kavramı eşyanın taşınmaz sayılması için yeterli değildir. Burada kanun koyucu, sosyal daha çok da ekonomik ihtiyaçlardan yola çıkarak bu hakları da taşınmaz olarak kabul etmiştir. (Gerçekten taşınır-taşınmaz ayrımında sadece eşyanın fiziksel özellikleri dikkate alınmamıştır. Nitekim fiziksel özellikleri itibariyle taşınır olan gemiler Türk Ticaret Kanununa göre taşınmaz kabul edilmiştir.) Bu kabul, hakların fiziksel özelliklerini değiştirmemekte sadece bunların bazı durumlarda taşınmaz gibi işlem görmesine neden olmaktadır. Aslında taşınmaz olarak sayılıp tapuya tescil edilen bu haklar devir kabiliyeti olan ve kişiye bağlı irtifak haklarından ${ }^{2}$ başka bir şey değildir. Mütemmim cüz prensibinin bir istisnası olan bu haklar ilişkin oldukları arazinin üstünde veya altında mülkiyetten bağımsız olarak hak sahibinin mülkü durumundadır. Tapu kütüğüne ayrı sayfada kaydedilen bağımsız ve sürekli haklar, üst hakkı ${ }^{3}$ (inşaat hakkı) ve kaynak hakkıdır. ${ }^{4}$

Kat mülkiyeti kütüğüne bağlı bağımsız bölümler, bir binanın başlı başına kullanılan ve kat mülkiyeti hükümlerine göre bağımsız mülkiyete konu bölümleridir.( Özdamar, 2006: 94.)

Türk hukuk sisteminde taşınmazın tanımı özel durumlar dışında Türk Medeni Kanununa bakılarak tayin edilir. Buna Türk vergi sistemi de dahildir. Vergi kanunlarının belirli maddelerinde taşınmaz kavramından ne anlaşılması gerektiği belirtilmediği sürece taşınmaz kavramı için Türk Medeni Kanununun ve sözlük anlamının esas alınması gerekmektedir (Alptürk, 2007: 4).

Bu durum şu şekilde ifade edilebilir. Vergi kanunlarının belirli maddelerinde taşınmaz kavramından ne anlaşılması gerektiği açıkça belirtilmediği sürece taşınmaz tanımından Türk Medeni Kanunundaki taşınmaz mülkiyetinin anlaşılacağı buna karşın vergi kanunlarının belirli maddelerinde ${ }^{5}$ taşınmaz kavramından ne anlaşılması

2 İrtifak Hakkı: Sahiplerine, başkasına ait bir şeyin üzerinde sadece kullanma ve yararlanma veya hem kullanma hem de yararlanma yetkisi veren haktır.

3 Bir kişinin başka bir kişiye ait arsa üstünde veya altında inşaat yapabilmesine ve mevcut inşaatı muhafaza edebilmesine yetki veren irtifak hakkı çeşididir.

4 Kaynak hakkı, bir kaynaktan (örneğin su kaynağı) herhangi bir surette yararlanma ya da onu kullanma yetkisi veren bir irtifak hakkıdır.

5 Vergi kanunlarında taşınmaz (gayrimenkul) kavramı direk olarak tanımlanmamış olsa da Gelir Vergisi Kanununun 70. maddesinde gayrimenkul sermaye iradının nelerden oluştuğu, aynı Kanunun mükerrer 80/6 maddede değer artış kazancının konusunu oluşturan taşınmaz unsurların neler olduğu ve 213 sayılı Vergi Usul Kanunun 269. maddesinde ise gayrimenkuller başlığı altında hangi kıymetlerin gayrimenkul gibi değerleneceği hüküm altına alınmıştır. Bu üç düzenleme dışında vergi kanunlarında gayrimenkul ifadesinden ne anlaşılması gerektiğine ilişkin özel bir düzenleme bulunmamaktadır. Hatta 1319 sayılı Emlak Vergisi Kanununda da taşınmaz tanımlanmamış sadece bina, arsa ve arazi kavramına ilişkin açıklamalar yapılmıştır. 
gerektiğinin açık ve net olarak belirtilmesi durumunda ise taşınmaz kavramından belirtilen anlamın yalnızca söz konusu maddeler için geçerli olacağı unutulmamalıdır.

Taşınmaz esas itibariyle bir yerden başka bir yere taşınamayan arz parçalarıdır. Taşınmazın tarifinde ise aşağıda verilen somut bileşenler vardır:

- Arazi,

- Ağaçlar ve mineraller gibi toprağın doğal ayrılmaz parçaları,

- Insanlar tarafından araziye bağlanmış binalar ve çevre düzenlemeleri gibi ekler.

Bunlara ek olarak bütün sabit bina ekleri (örneğin sıhhi tesisat, elektrik kablo sistemleri ve ısıtma sistemleri) ve binanın yapısına eklenen unsurlar da (kabinler ve asansörler gibi) genellikle taşınmazın bir parçası olarak kabul edilirler.(Gayrimenkul Değerlemesi, 2004: 7).

Taşınmaz çeşitleri kullanım amaçlarına veya mülkiyet esasına göre sınıflandırılabilir(Kabataş, 2005: 55.)

Taşınmazların kullanım amaçlarına göre sınıflandırılması dört ana gruba ayrılmaktadır. Bunlar: konutlar, işyerleri, arazi ve arsalar ve diğer yapılar şeklindedir.

Konutlar, ev, apartman veya lojman gibi ikamete ayrılmış yapılardır. İşyerleri ise ticari ve sinai amaçlı kullanılan taşınmazlardır. Dükkân, iş hanı, depo, fabrika, imalathane vb. yapılar bu grupta yer almaktadır.

Kullanım amaçlarına göre taşınmaz çeşitlerinden biri olan arazi, tapu siciline kaydedilmekte olup taşınmaz sayılmaktadır. Sınırları, yüzölçümü ve niteliği yeteri kadar belli edilmiş arazi parçasına ise parsel adı verilmektedir. Arazi yalnızca toprağın yüzeyini değil onun altındaki ve üstündeki her şeyi de içerir. Arsa ise şekil ve büyüklük bakımından öngörülen imar aracı ile bölünmüş, gerekli yol ağı yapılıp, su ve elektrik ihtiyacı giderilmiş ve kanalizasyona bağlantısı hazırlanmış imar parselidir.

Konut ve işyeri dışında kalan yapılar ise diğer yapılar şeklinde ifade edilebilir. Bu grup içerisinde daha çok dini yapılar içerisinde kullanılan cami ve kilise vb. yapılar yer almaktadır.

Gelir Vergisi Kanunu tasarısının genel gerekçesinde amaçlanan unsurlardan biri olan vergi tabanının genişletilmesi ve vergi adaletinin pekiştirilmesi ilkesi gereği; kentsel rantların ve sermaye kazançlarının vergilendirilmesindeki istisnaların daraltıldığı, ayrıca gerek taşınmazlardaki değer artışlarının gerekse bunlar üzerinden elde edilen rantların bir kısmının kamuya aktarılmasının zorunlu olduğu ifade edilmiştir.

Rant kavramı özellikle gelir vergisi kanunu tasarısı ile birlikte çok sık konuşulmaya ve kamuoyunda tartışılmaya başlayan bir konu haline gelmiştir. Hatta tasarı kentsel rantların vergilendirilmesi kavramı ile özdeşleştirilmektedir. Bu çalışmada da temel amacımız rant kavramı ve kuramlarını tartışmak olmamakla beraber rant kavramının ne anlama geldiğinin bilinmesi ve oluşan rantın vergilendirilmesine ilişkin ülkemiz vergi uygulamalarından kısaca bahsetmek yararlı olacaktır. 
Fransızca (rente) sözcügü̈nden dilimize giren rant sözcüğü; genelde tarla, arazi vb gibi taşınmaz mülkiyetinin toprağı işleme, kullanma hakkı karşılığında belirli zaman dilimleri sonunda elde ettiği ve emeğe dayanmayan gelir olan toprak rantı (Büyük Larousse Sözlük ve Ansiklopedisi) ya da sosyal ve ekonomik koşullar gereği ortaya çıkan ekonomik yapı sonucu bir ya da birkaç üretim faktörünün olağan getirisine eklenen fazladan kazanç şeklinde tanımlanmaktadır. Yine toprak rantı ile bağlantılı olarak gayrimenkul rantı kavramı da ortaya çıkmıştır. (Açlar \& Çağdaş, Taşınmaz Değerlemesi, s.10)

Gayrimenkul rantı kavramı değişik kaynaklarda ifade edilmekte ve emek ve sermaye gereksinimi olmaksızın taşınmaz sahibinin iradesi dışında zaman içinde meydana gelen değer artışı olarak tanımlanmaktadır.(Kaya, Gayrimenkul Rantlarının Vergilendirilmesi, http://www.vmhk.org.tr/gayrimenkul-rantların-vergilendirilmesi/)

Ekonomik gelişmeler ve ekonomik anlayışlarda ortaya çıkan değişiklikler sonucu toprakta ortaya çıkan rant kavramı genişlemiştir. Sanayileşen toplumlarda hızla artan kent nüfusu; bu tür yerleşim alanlarındaki arsa ve arazi fiyatlarının hızla yükselmesine neden olmuştur. Henry George ise kent topraklarında ortaya çıkan bu emeksiz gelire kentsel rantadını vermiştir. Hatta Henry George "ilerleme ve Yoksulluk, 1879" isimli eserinde oluşan bu rantın vergi yoluyla kamuya aktarılmasını ve geri alınmasını istemiştir. (Açlar \& Çağdaş, Taşınmaz Değerlemesi, s.10)

Ülkemiz maliye tarihi açısından kentsel rantların kamuya aktarılması kapsamında özellikle maliye kaynaklarında farklı vergi türleri ve uygulamaları anlatılmaktadır. Bunlar 1948 tarihli "Değerleme Resmi", 1970 tarihli "Gayrimenkul Kıymet Artışı Vergisi”, halen uygulanmakta olan 193 sayılı Gelir Vergisi Kanununda yer alan ve çalışmanın konusunu da oluşturan "Değer Artış Kazançlarına İlişkin Hükümler", ile 2464 sayılı Belediye Gelirleri Kanununda yer alan "Harcamalara Katılma Payları" rant vergisi olarak ifade edilmektedir. Ülkemiz açısından oluşan kentsel rantların vergilendirilmesi aşamasında geçmiş dönem uygulamalarına bakıldığında 1948 tarihli 5237 sayılı Belediye Gelirleri Kanununda yer alan "Değerleme Resmi" en güzel örnektir. ${ }^{6}$ Yine 1970 tarihli Finansman Kanunu ile getirilen ve 1970-1982 yılları arasında uygulanan "Gayrimenkul Kıymet Artışı Vergisi" de rantların kamuya aktarılmasında önemli vergi uygulamaları olarak karşımıza çıkmaktadır. ${ }^{7}$ Günümüzde ise bazı kaynaklarda Belediye Gelirleri Kanununda yer alan harcamalara katılma paylarının bir rant vergisi olduğu ifade edilmektedir. Ancak harcamalara katılma payları taşınmazlarda oluşan değer artışlarını vergilendirmemekte öngörülen harcamanın bir kısmını finanse etmek için alınmaktadır (Nadaroğlu, 1998: 197). Bu şekliyle vergiden uzak bir yapıdadır. 2464 sayılı Belediye Gelirleri Kanununda yer alan harcamalar katılma payları yol harcamalarına katılma payları, kanalizasyon harcamalarına katılma payları ve su tesisi harcamalarına katılma paylarından oluşmaktadır. Mevcut düzenlemede vergi hukuku açısından ilginç bir durumda söz konusudur. Yol harcamalarına katılma paylarını düzenleyen madde hükmünde bu katılma payı ile ilgili olarak "alınabilir" ifadesi kullanılmasına karşın kanalizasyon ve su

6 Bu konu ile ilgili olarak ayrıntılı bilgiye 9 Temmuz 1948 tarih ve 6953 sayılı Resmi Gazete'de yayımlanan Belediye Gelirleri Kanunundan ulaşabilirsiniz.

7 Gayrimenkul Kıymet Artışı Vergisi ile ilgili ayrıntılı bilgiye Kenan Bulutoğlu, Türk Vergi Sistemi Cilt:2 Ankara, 1979'dan ulaşabilirsiniz. 
tesisi harcamalarına katılma paylarına ilişkin madde hükmünde ise "alınır" ifadesi yer almaktadır. Dolayısıyla harcamalara katılma paylarından biri olan ve rant vergisi olarak ifade edilebilen yol harcamalarına katılım payının bırakın rant vergisi olmasını bir zorunluluk içermediği için zorunlu yükümlülük olarak değerlendirilip değerlendirilemeyeceği bile tartışılır bir durumdadır. ${ }^{8}$

Vergiye çok yaklaşan zorunlu bir yükümlülük olan şerefiye ise, yapılan bayındırlık ve alt yapı hizmetleriyle imar faaliyetlerinden dolayı bazı taşınmaz sahiplerinin mal varlıklarındaki değer artışlarının vergilendirilmesi olarak tanımlanmaktadır. Bu değer artışında sözü geçen taşınmazlara sahip olanların bir rolü ve katkısı yoktur. Bu gibi durumlarda mal varlığında değer artışı meydana gelenlerin bir ödemede bulunmalarının haklı olacağı düşünülmekte ve bu amaçla salınan yükümlülüğe şerefiye denilmektedir. (Nadaroğlu, 1998 s.197). Bu açıdan bakıldığında geçmiş dönemlerde uygulanan "değerleme resmi" ve "gayrimenkul kıymet artışı vergisi" bir nevi şerefiyedir. Ancak harcamalara katılma payı ise yukarıda da ifade edildiği üzere şerefiyeye son derece benzemekle birlikte sadece öngörülen harcamanın bir kısmını finanse etmek için alınmaktadır.

Mevcut mevzuatımızda sadece 193 sayılı Gelir Vergisi Kanunu kapsamında "değer artış kazançlarına" ilişkin hükümler kentsel rantların vergilendirilmesine yönelik bir düzenlemedir. Burada şu hususunda unutulmaması gerekmektedir. Taşınmazlara ilişkin rant, merkezi ve yerel yönetimlerin özellikle bayındırlık yatırımları, imar düzenlemeleri, ulaşım ve kentsel dönüşüm projeleri ile oluşmaktadır. Oluşan bu rantlar ise alım-satım kazancı ile kira getirisinden kaynaklanmakta ve satış ve kira geliri elde edildiğinde ortaya çıkmaktadır. Dolayısıyla rant vergilendirilmek isteniyor ise verginin bu aşamalarda alınması gerekmektedir.

\section{193 Sayılı Gelir Vergisi ve 5520 Sayılı Kurumlar Vergisi Kanunlarına Göre Taşınmazların Elden Çıkarılmasında Elde Edilen Gelirin Vergilendirilmesi: Mevcut Durum}

Mevcut mali mevzuat hükümlerine göre, Gelir Vergisi Kanununda gelir, bir gerçek kişinin bir takvim yılı içinde elde ettiği kazanç ve iratların safi tutarı olarak tanımlanmış, hangi tür kazanç ve iratların gelire dahil olduğu ve gelirin nelerden oluştuğu ayrıca ifade edilmiştir.

Bir gelirin vergiye tabi olabilmesi için gelir türlerinden birine girmesi gerekmektedir. Her gelir unsuru için farklı vergileme teknikleri öngörüldüğünden, kazanç ve iratların hangi gelir unsurunun kapsamına girdiğinin tespiti son derece önemlidir.

Gerçek kişilerin sahip oldukları taşınmazları elden çıkarmalarından doğan kazancın niteliği ve vergilendirilmesi hakkında, Gelir Vergisi Kanununda iki ayrı gelir

\footnotetext{
8 Harcamalara katılım payları ve şerefiye ile ilgili olarak ayrıntılı bilgiye Halil Nadaroğlu, Kamu Maliyesi Teorisi, 1998'den ulaşabilirsiniz.
} 
türünde düzenlemeye yer verilmiştir. Bunlardan ilki "ticari kazanç", diğeri ise "diğer kazanç ve iratlar" hükümlerinde yer alan düzenlemedir.

a) Ticari kazanç: Her türlü ticari ve sınai faaliyetten doğan kazançtır. Ticari kazancı belirleyen temel unsur faaliyetin sermaye ve emekten oluşan bir organizasyona dayanması ve bu organizasyonun işlemlerindeki devamlılıktır. Gelir Vergisi Kanununun 37. Maddesinde "taşınmazların alım satımı ve inşa işleriyle devamlı olarak uğraşanların bu işlerden elde ettikleri kazançların" ticari kazanç olarak vergilendirileceği belirtilmiştir.

b) Diğer kazanç ve iratlar: Belirli kaynaklara bağlanması mümkün olmayan, belirli dönemlerde (periyodik olarak) meydana gelmeyen, devamlı değil arızi olan ve çoğu zaman bir teşebbüs sonucu olmaksızın, kişilerin bazı mal varlıklarında kendiliğinden meydana gelen kazanç ve iratlardır. Bu gelir türünü diğerlerinden ayıran en önemli özellik, devamlılık göstermeyen gelirlerin bu kapsamda değerlendirilmiş olmasıdır. Diğer kazanç ve iratlar, Gelir Vergisi Kanununun 80 ve 82 . maddelerinde "değer artış kazançları" ve "arızi kazançlar" olmak üzere iki alt ayrıma tabi tutulmuştur.

Taşınmazların elden çıkarılmalarından doğan kazancın niteliğinin belirlenmesi, yani kazancın diğer kazanç ve iratlar gelir türündeki "değer artış kazancı" olarak mı, yoksa ticari kazanç mı olarak vergilendirilmesi gerektiğinin belirlenmesi önem arz etmektedir.

Taşınmaz alım satım işinden elde edilen gelirin niteliğinin belirlenmesinde ilk önemli unsur faaliyetteki devamlılıktır. Taşınmaz alım satım işleri devamlı olarak, bir meslek halinde sürdürülüyorsa elde edilen kazanç ticari kazançtır. Burada devamlılık unsurunu belirleyen en belirleyici ölçüt kazanç doğuran işlem sayısındaki çokluktur. İ̧lem sayısındaki çokluk taşınmazların aynı takvim yılı içerisinde birden fazla veya takip eden birden fazla takvim yılında art arda satılmış olmasına göre belirlenir. (Gelir İdaresi Başkanlığı, 2014,s.7 ) Türk vergi sisteminde elde edilen gelirin kazanç veya irat olarak vergilendirilmesi husussunda faaliyette devamlılık çok tartışılan bir kriter olup çoğu zaman mükellef ile idare arasında uyuşmazlık konusu olabilmektedir. Bu açıdan bakıldığında taşınmaz satışından elde edilen gelirin niteliğinin belirlenmesinde bu kriterin tek başına dikkate alınması yapılan işlemi yanlışlığa sürükleyebilecektir.

Alım satım işlemlerinin birden fazla olması halinde kazanç şeklinin belirlenebilmesi için ikinci önemli unsur olan satıșın hangi amaçla yapıldığının" tespit edilmesi gerekmektedir.

Taşınmaz alım satımı kazanç elde etmek için yapılıyorsa söz konusu alım-satım işlemi ticari kazanç kapsamında değerlendirilir.

Taşınmaz alım satımında ticari bir amaç yoksa şahsi ihtiyacın karşılanması ya da servetin korunması amacıyla yapılıyorsa elde edilen kazanç değer artış kazancı olarak değerlendirilir.

Taşınmaz alım satım işinden elde edilen gelirin niteliğinin belirlenmesinde üçüncü önemli unsur ise ticari bir organizasyonun varlığıdır.

Taşınmaz alım satımı, şekli ve maddi şartları ile kurulmuş bir ticari organizasyon içinde yapılıyorsa elde edilen kazanç ticari kazançtır. Ticari organizasyonun şekli ve 
maddi unsurları ile açıkça belli olmadığı hallerde ise kazanç türü "faaliyetteki devamlılık" ve "satışın hangi amaçla yapıldığı" unsurlarına göre tespit edilir.(Gelir İdaresi Başkanlığı, 2014: 7)

Açıklamalardan da anlaşılacağı üzere taşınmazların gerçek kişiler tarafından elden çıkarılmasında ise vergileme açısından üç durum söz konusu olmaktadır. Bu işlem sonucunda elde edilen kazanç; ya ticari kazanç olacak, ya belli durumlarda diğer kazanç ve irat (değer artış kazancı) olacak veya belli şartlar dahilinde gelir vergisinin konusuna girmeyecektir.

Taşınmazın elden çıkarılmasından doğan kazançlar devamlılık arz etmemek ve ticari bir organizasyon dahilinde yapılmamak koşuluyla değer artış kazancı olarak vergilenmektedir. Taşınmaz satışının devamlılık arz etmesi ve bu faaliyetin ticari bir organizasyon içinde sürdürülmesi halinde ise elde edilen kazanç ticari kazanç olarak vergilendirilmektedirler.(Kızılot vd., 2005: 42)

Ticari organizasyon ve süreklilik olmaksızın arızi olarak yapılan taşınmaz satış kazançlarının vergilendirilmesiyle ilgili mevcut düzenleme şu şekildedir. ${ }^{9}$

01.01.2003 tarihinden sonra elde edilen değer artış kazançları, 4783 sayılı Kanunla yeniden düzenlenen mükerrer 80,81 . maddeleri hükümlerine göre vergileme yapılmaktadır.

Taşınmaz satış kazançlarının vergilendirilmesine ilişkin olarak yukarıda belirtilen düzenlemeler sonucu Gelir Vergisi Kanununun mükerrer 80. maddesinin 6. fıkrası hükmü şu şekildedir. "iktisap şekli ne olursa olsun (ivazsız olarak iktisap edilenler hariç) 70. maddenin birinci fıkrasının 1, 2, 4 ve 7 numaralı bentlerinde ${ }^{10}$ yazılı mal (gerçek usulde vergiye tabi çiftçilerin zirai üretimde kullandıkları taşınmazlar dahil) ve hakların iktisap (edinme) tarihinden başlayarak 5 yıl içinde ${ }^{11}$ elden çıkarılmasından doğan kazançlar (kooperatif ortaklarına bu sıfatları dolayısıyla tahsis ettikleri taşınmazları tahsis tarihinde ortak tarafından satın almış sayılır) değer artış kazancıdır."

9 Ticari organizasyon ve süreklilik olmaksızın arızı olarak yapılan taşınmaz satış kazançlarının vergilendirilmesiyle ilgili olarak yapılan ana düzenlemeler 27.12.1980 tarih ve 17203 sayılı Resmi Gazete'de yayımlanan 2361 sayılı kanun, 14.08 .1999 tarih ve 23786 sayılı Resmi Gazete'de yayımlanan 4444 sayılı kanun, 09.01 .2003 tarih ve 24988 sayılı Resmi Gazete'de yayımlanan 4783 sayılı kanun, 31.12.2004 tarih ve 25687 sayılı Resmi Gazete'de yayımlanan 5281 sayılı kanun ve son olarak 04.04.2007 tarih ve 26483 sayılı Resmi Gazete'de yayımlanan 5615 sayılı kanundur.

10 Gelir Vergisi Kanununun 70. maddesi, gayrimenkul sermaye iradının tarifine yönelik olup, birinci fıkranın 1, 2, 4 ve 7 numaralı bentlerinde sırasıyla arazi ve bina, voli mahalleri ve dalyanlar, gayrimenkul olarak tescil edilen haklar ve gemi ve gemi payları ile bilumum bütün motorlu tahmil yükleme, tahliye ve boşaltma vasıtaları yer almaktadır.

115615 sayılı kanunla yapılan değişiklik sonrası ivazsız olarak iktisap edilenler hariç kanunda sayılan mal ve hakların, iktisap tarihinden başlayarak, beş yıl içinde elden çıkarılmasından doğan kazançlar değer artış kazancı sayılacaktır. Bir başka ifade ile söz konusu mal ve hakların elden çıkarılmasından doğan kazançların vergilenmemesi için iktisap tarihinden itibaren beş yıl süreyle elde tutulması gerekmektedir. Ancak 5615 sayılı Kanunla yapılan değişiklik 01.01.2007 tarihinden sonra iktisap edilen mal ve haklar için söz konusudur. Zira anılan Kanun'un 11'nci maddesi ile GVK'na eklenen geçici 71. maddede 01.01.2007 tarihinden önce iktisap edilmiş olan mal ve hakların elden çıkarılmasından doğan kazançların vergilendirilmesinde dört yıllık sürenin esas alınacağı hükme bağlanmıştır. Daha ayrıntılı bilgi için bkz; Mehmet Emin Akyol, "Gayrimenkullere illişkin Değer Artış Kazançlarına Yeni Düzenleme" Yaklaşım Dergisi. Sayı:173 (Mayıs 2007), s.44. 
Değer artış kazançlarında vergiyi doğuran olay söz konusu mal ve hakların elden çıkartılmasıdır. Gelir Vergisi Kanununun ilgili hükmüne göre, elden çıkarma deyimi ile söz konusu mal ve hakların satılması, bir ivaz karşılığında devir ve temliki, trampa edilmesi, takası, kamulaştırılması, devletleştirilmesi ve ticaret şirketlerine sermaye olarak konulması ifade edilmektedir. Elden çıkarma karşılığında sağlanan ve para ile temsil edilen her türlü çıkarın toplam tutarı ${ }^{12}$ değer artış kazancının hesaplanmasında gayri safi hasılat olarak ele alınmaktadır. Bu tutardan elden çıkarılan taşınmazın maliyet bedeli $^{13}$ ile elden çıkarma dolayısıyla satıcının yaptığı giderler ve ödenen vergi ve harçların indirilmesiyle safi tutarı bulunmaktadır. (Baydemir, 2006: 221.)

Gelir Vergisi Kanununun mükerrer 81. maddesine göre maliyet bedelinin mükellefçe tespit edilememesi halinde maliyet bedeli yerine Vergi Usul Kanunu hükümlerine göre takdir komisyonlarınca tespit edilecek bedel, kazancı bilanço veya işletme hesabı esasına göre tespit edilen işletmelerde ise son bilançoda veya envanter kayıtlarında gösterilen değer esas alınmaktadır.

Yine anılan Kanunun mükerrer 81. maddesinde taşınmazın elden çıkarılmasında iktisap bedeli elden çıkarılan taşınmazın (bina, arsa ve arazinin) elden çıkarıldığı ay hariç olmak üzere Türkiye İstatistik Kurumunca (TÜiK) belirlenen toptan eşya fiyat endeksindeki artış oranında artırılarak tespit edileceği hüküm altına alınmıştır.2006 yılının Ocak ayından itibaren toptan eşya fiyat endeksi yerine, üretici fiyat endeksi (ÜFE) yayımlanmaktadır. Bu nedenle 01.01.2006 tarihinden sonra yapılan endekslemelerde toptan eşya fiyat endeksi yerine, üretici fiyat endeksi (ÜFE) dikkate alınmaktadır. Ancak bu endekslemenin yapılabilmesi için artış oranının yüzde 10 veya üzerinde olması şarttır.

Taşınmazların elden çıkarılmasından sağlanan değer artış kazancının 2016 takvim yılı gelirlerine uygulanmak üzere 11.000 TL'si vergiden istisna tutulmuştur.

Taşınmazların elden çıkarılmasından doğan kazançların yukarıda belirtilen ilgili madde hükümlerine göre değer artış kazancı olarak vergilendirilebilmesi için:

- Öncelikle elden çıkarılan taşınmazın bir bedel karşılığında edinilmiş olması,

12 Taşınmazların elden çıkarılmasından doğan değer artış kazancının hesaplanmasında elden çıkarma bedeli ise;

-Nakit karşılığı satış halinde satış bedeli,

-ivaz karşılı̆̆ı devir ve temlikte devir ve temlik karşılığı alınan ivaz,

-Kamulaştırma ve devletleştirmede alınan istimlak bedelidir.

-Ayın ve menfaat olarak sağlanan hasılatın değeri VUK'nun değerleme hükümlerine göre tespit edilmektedir.

-Trampa veya takas halinde ise elden çıkarılan kıymet karşılığında alınan mal ve hakların VUK'nun değerleme ile ilgili hükümlerine göre tespit edilecek değeri esas alınmaktadır.

-Trampa veya takas halinde ise elden çıkarılan kıymet karşılığında alınan mal ve hakların VUK'nun değerleme ile ilgili hükümlerine göre tespit edilecek değeri esas alınmaktadır.

${ }^{13}$ Vergi Usul Kanunun 262. maddesinde Maliyet Bedeli, iktisadi bir kıymetin iktisap edilmesi veyahut değerinin artırılması münasebetleriyle yapılan ödemelerle bunlara müteferri (ödenen komisyonlar, taşıma ücretleri vb) bilumum giderler toplamını ifade eder. 
- Iktisap tarihinden itibaren 5 yıl $^{14}$ içinde elden çıkarılması,

- Elde edilen kazancın elde edildiği yıl için belirlenen istisna tutarını aşması gerekmektedir.

Taşınmazların kurumlar vergisi mükellefleri tarafından elden çıkarılmasında ise mevcut yasal düzenlemelerde bir istisna bulunmaktadır. Buna göre 5520 sayılı Kurumlar Vergisi Kanununda taşınmaz ticareti ve kiralanmasıyla uğraşan kurumların bu amaçla ellerinde bulundurdukları taşınmazların satışından elde ettikleri kazançlar hariç olmak üzere taşınmaz satış kazançlarına bir istisna getirilmiştir. Anılan Kanunun "İstisnalar" başlıklı 5. maddesinin birinci fıkrasının (e) bendinde yer alan istisnada "Kurumların, en az iki tam yıl süreyle aktiflerinde yer alan taşınmazlar ve iştirak hisseleri ile aynı süreyle sahip oldukları kurucu senetleri, intifa senetleri ve rüçhan haklarının satışından doğan kazançların \% 75'lik kısmı istisnadır. Taşınmazların; kaynak kuruluşlarca, kira sertifikası ihracı amacıyla varlık kiralama şirketlerine satışı ile 6361 sayılı Finansal Kiralama, Faktoring ve Finansman Şirketleri Kanunu kapsamında geri kiralama amacıyla ve sözleşme sonunda geri alınması şartıyla, finansal kiralama şirketlerine satışı ve varlık kiralama ile finansal kiralama şirketlerince taşınmazın devralındığı kuruma satışından doğan kazançlar için bu oran \%100 olarak uygulanır ve bu taşınmazlar için en az iki tam yıl süreyle aktifte bulunma şartı aranmaz. Ancak söz konusu taşınmazların; kaynak kuruluş, kiracı veya sözleşmeden kaynaklanan yükümlülüklerin yerine getirilememesi hâli hariç olmak üzere, varlık kiralama veya finansal kiralama şirketi tarafından üçüncü kişi ve kurumlara satılması durumunda, bu taşınmazların kaynak kuruluşta veya kiracıdaki varlık kiralama veya finansal kiralama şirketine devirden önceki kayıtlı değeri ile anılan kurumlarda ayrılan toplam amortisman tutarı dikkate alınarak satışı gerçekleştiren kurum nezdinde vergilendirme yapılır.)

Bu istisna, satışın yapıldığı dönemde uygulanır ve satış kazancının istisnadan yararlanan kısmı satışın yapıldığı yılı izleyen beşinci yılın sonuna kadar pasifte özel bir fon hesabında tutulur. Ancak satış bedelinin, satışın yapıldığı yılı izleyen ikinci takvim yılının sonuna kadar tahsil edilmesi şarttır. Bu süre içinde tahsil edilmeyen satış bedeline isabet eden istisna nedeniyle zamanında tahakkuk ettirilmeyen vergiler ziyaa uğramış sayılır.

İstisna edilen kazançtan beş yıl içinde sermayeye ilave dışında herhangi bir şekilde başka bir hesaba nakledilen veya işletmeden çekilen ya da dar mükellef kurumlarca ana merkeze aktarılan kısım için uygulanan istisna dolayısıyla zamanında tahakkuk ettirilmeyen vergiler ziyaa uğramış sayılır. Aynı süre içinde işletmenin tasfiyesi (bu Kanuna göre yapılan devir ve bölünmeler hariç)halinde de bu hüküm uygulanır.

\footnotetext{
145 yıllık sürenin hesabında iktisap tarihi;

-Satın almada iktisap tarihi tapuya tescil tarihidir.

-Kooperatif ortaklarına tahsis edilen taşınmazlar tahsis tarihinde iktisap edilmiş sayılır.

-Inşa edilen taşınmazlarda yapı kullanma belgesinin alındığı tarih geçerlidir.

-Arsa karşılığı daire alanlarda, inşaatın tamamlanıp yapı kullanma izin belgesinin alındığı tarih esastır.

-Cebri icra ve şuyun izalesiyle (ortaklığın sona ermesi) satın almada tapuya tescilden önce resmi işlemin tamamlanmasıyla iktisap gerçekleşmektedir.
} 
Devir veya bölünme suretiyle devralınan taşınmazlar, iştirak hisseleri, kurucu senetleri ve intifa senetleri ile rüçhan haklarının satışında iki yıllık sürenin hesabında, devir olunan veya bölünen kurumda geçen süreler de dikkate alınır.

Bedelsiz olarak veya rüçhan hakkı kullanılmak suretiyle itibarî değeriyle elde edilen hisse senetlerinin elde edilme tarihi olarak, sahip olunan eski hisse senetlerinin elde edilme tarihi esas alınır.

Devir veya bölünme suretiyle devralınan taşınmazlar, iştirak hisseleri, kurucu senetleri ve intifa senetleri ile rüçhan haklarının satışında iki yıllık sürenin hesabında, devir olunan veya bölünen kurumda geçen süreler de dikkate alınır.

Menkul kıymet veya taşınmaz ticareti ve kiralanmasıyla uğraşan kurumların bu amaçla ellerinde bulundurdukları değerlerin satışından elde ettikleri kazançlar istisna kapsamı dışındadır." hükmü yer almıştır.

Görüldüğü üzere, taşınmaz satışından elde edilen kazanç, ister gelir vergisinin konusuna girsin ister kurumlar vergisinin konusuna girsin taşınmazın elden çıkarılmasından elde edilen kazancın vergilendirilmesinde taşınmazın gerçek iktisap ve satış bedelinin tespiti önem taşımaktadır.

\section{Gelir Vergisi Kanunu Tasarısına Göre Taşınmazların Elden Çıkarılmasında Elde Edilen Gelirin Vergilendirilmesi}

Gelir vergisi Kanunu Tasarısı genel gerekçesinde 193 sayılı Gelir Vergisi Kanununun yeniden yapılandırılması ile ilgili temel gerekçeler şu şekilde ifade edilmiştir.

Mevcut 193 sayılı Gelir Vergisi Kanunu, 1960 yılında kabul edilmiş ve o tarihten bu zamana kadar birçok maddesinde 76 farklı Kanunla değişiklik yapılmış, ek, geçici ve mükerrer maddelerle birlikte madde sayısı 210'u aşmıştır. Ayrıca, gelir unsurları ile bu unsurlara ilişkin istisna, indirim ve diğer müesseseler Kanunun değişik bölümlerinde dağınık halde bulunmasının da bir sonucu olarak Gelir Vergisi Kanununda yer alan bazı temel müesseseler geçici maddeler ile yönlendirilir bir hal almıştır. Yeni Gelir Vergisi Kanunu basit, sade ve kolay anlaşılabilir bir yapıda hazırlanması amaçlanmış ve şu ilkeler esas alınmıştır. (Yeni GVK Tasarısı: http://www.maliye.gov.tr/Lists/ HaberlerListesi/Attachments/95/ GVK\%20Sunum.pdf)

- Adil bir gelir vergisi sistemi oluşturmak

- Yatırım, üretim ve istihdamı desteklemek

- Ekonominin rekabet gücünü artırmak

- Mükelleflerin vergiye gönüllü uyumunu teşvik etmek

- Kayıtlı ekonomiye geçişi hızlandırmak

- Vergiyi tabana yaymak

$\mathrm{Bu}$ ilkeler çerçevesinde tasarı ile ilgili olarak gerekçede şu ifadelerde yer almaktadır. "Bu tasarı ile gerçek ve tüzel kişilerin kazançları üzerinden alınacak vergiler 
birleştirilerek tek bir kanun bünyesinde toplanmakta, 193 sayılı Gelir Vergisi Kanunu ile 5520 sayılı Kurumlar Vergisi Kanunu'nun yürürlükten kaldırılması öngörülmektedir. (Hâlihazırda ek, geçici ve mükerrer maddeleriyle birlikte Gelir Vergisi Kanunu 210 maddeden fazladır. Kurumlar Vergisi Kanunu ise 45 maddedir. iki kanunu birleştiren yeni Gelir Vergisi Kanunu ise sadece 95 maddeden oluşmaktadır.)Şüphesiz ki; değişikliklerin kapsamını Gelir Vergisi Kanunu ile Kurumlar Vergisi Kanununun dünyadaki yaygın uygulamalara paralel olarak tek kanun haline getirilmesi ile sınırlamak doğru olmayacaktır." Ayrıca gerekçede mevcut yapıya ilişkin bazı değerlendirmelere ilave olarak gelir üzerinden alınan vergilere yönelik şu tespitte yapılmıştır. "Ülkemizde gelir ve kazançlar üzerinden alınan vergilerin, vergi kapasitesinin altında kalması dolaysı vergilerin toplam vergi gelirleri içerisindeki payının düşük olması sonucunu doğurmakta, bu durum ise vergi adaletini zedelemektedir. Nitekim Türkiye'de gelir ve kazançlar üzerinden alınan vergilerin GSYH'ye oranı yaklaşık \%6 gibi oldukça düşük bir seviyededir. Oysa son verilere göre O.E.C.D. ülkelerinde bu oran \%11,4'tür. Türkiye, O.E.C.D. ülkeleri arasında gelir ve kazanç üzerinden alınan vergilerde en düşük vergi yüküne sahip üçüncü ülkedir." (Yeni GVK Tasarısı: http://www.maliye.gov.tr/Lists/HaberlerListesi/Attachments/95/ GVK\%20Sunum.pdf)

Tasarının geneline bakıldığında, gelir üzerinden alınan vergilerin vergi gelirleri içindeki payını artırma, vergi tabanının genişletilmesi ve vergi adaletinin sağlanması gibi hedefleri de olup; kentsel rantların ve sermaye kazançlarının vergilendirilmesindeki istisnaların daraltıldığı da gerekçede belirtilmiştir. Ayrıca beyanname veren mükellef sayısında artış da öngörülmektedir. Diğer taraftan tasarı, gelir ve kazançlar üzerinden alınan vergileri düzenleyen ve Türk Vergi Sisteminin temel unsurlarını teşkil eden 5421, 5422, 193 ve 5520 sayılı kanunların üzerine inşa edilmiştir. Bu çerçevede tasarıda yer alan düzenlemelerin teke tek ele alınması yerine; halen yürürlükte olan 193 ve 5520 sayılı kanunlarla karşılaştırması öne çıkarılarak bu çalışma yapılmıştır. Çalışmamızın temel amacı tasarıda öngörülen düzenlemelerin mevcut yapıdan farkını ortaya koymak ve öneriler getirilmektedir. (Yeni GVK Raporu, Mazars Denge, http://www.mazars.com.tr/Anasayfa/Haberler/Rapor-Arastirmalar/Yeni-Gelir-Vergisi Kanunu-Tasarisi, s.4)

Gelir Vergisini Kanunu Tasarısına göre, taşınmazların elden çıkarılmasında elde edilen gelirin vergilendirilmesinde ticari kazancını bilanço esasına göre tespit eden gerçek kişiler ile kurumların aktifindeki taşınmazlara ilişkin olarak 21. maddede "ìstisna Kazançlar" başlığı altında; diğer gerçek kişiler açısından ise 45, 46, 47, 48 ve 49. maddeler de "Değer Artış Kazançları" başlığı altında düzenlemeler yer almaktadır.

Tasarının 21. maddesindeki İstisna Kazançlar ilişkin düzenleme şu şekildedir.

MADDE 21- (1) Ticari kazancını bilanço esasına göre tespit eden gerçek kişiler ile kurumların aktiflerindeki taşınmazlar, iştirak hisseleri, kurucu senetleri, intifa senetleri ve rüçhan haklarının satışından doğan kazançlar aşağıda belirtilen süre, oran ve şartlar çerçevesinde gelir vergisinden müstesnadır:

a) Yukarıda sayılan mal ve hakların elde tutma süresine bağlı olarak, satışından doğan kazanca uygulanacak istisna oranları aşağıdaki gibidir: 
1) iki tam yıldan sonra satıştan doğan kazançlarda \%40.

2) Üç tam yıldan sonra satıştan doğan kazançlarda \%50.

3) Dört tam yıldan sonra satıştan doğan kazançlarda \%60.

4) Beş tam yıldan sonra satıştan doğan kazançlarda \%75.

c) Bu istisna, satışın yapıldığı dönemde uygulanır ve satış kazancının istisnadan yararlanan kısmı satışın yapıldığı yılı izleyen beşinci yılın sonuna kadar pasifte özel bir fon hesabında tutulur. Ancak satış bedelinin, satışın yapıldığı yılı izleyen ikinci takvim yılının sonuna kadar tahsil edilmesi şarttır. Bu süre içinde tahsil edilmeyen satış bedeline isabet eden istisna nedeniyle zamanında tahakkuk ettirilmeyen vergiler ziyaa uğramış sayılır. Taşınmazların; kaynak kuruluşlarca, kira sertifikası ihracı amacıyla varlık kiralama şirketlerine satışı ile 6361 sayılı Finansal Kiralama, Faktoring ve Finansman Şirketleri Kanunu kapsamında geri kiralama amacılla ve sözleşme sonunda geri alınması şartıyla, finansal kiralama şirketlerine satışı ve varlık kiralama ile finansal kiralama şirketlerince taşınmazın devralındığı kuruma satışından doğan kazançlar için bu oran \%100 olarak uygulanır ve bu taşınmazlar için süre şartı aranmaz. Ancak, söz konusu taşınmazların, kaynak kuruluş, kiracı tarafından veya sözleşmeden kaynaklanan yükümlülüklerin yerine getirilememesi hali hariç olmak üzere, varlık kiralama veya finansal kirama şirketi tarafından üçüncü kişi ve kurumlara satılması durumunda, bu taşınmazların kaynak kuruluşta veya kiracıdaki varlık kiralama veya finansal kiralama şirketine devirden önceki kayıtlı değeri ile anılan kurumlarda ayrılan toplam amortisman tutarı dikkate alınarak satışı gerçekleştiren kurum nezdinde vergilendirme yapilır.

c) İstisna edilen kazançtan beş yıl içinde sermayeye ilave dışında herhangi bir şekilde başka bir hesaba nakledilen veya işletmeden çekilen ya da dar mükellef kurumlar tarafından ana merkeze aktarılan kısım için uygulanan istisna dolayısıyla zamanında tahakkuk ettirilmeyen vergiler ziyaa uğramış sayılır. Bu Kanuna göre yapılan devir ve bölünmeler hariç aynı süre içinde işletmenin tasfiyeye girmesi halinde de bu hüküm uygulanır.

e) Devir veya bölünme suretiyle devralınan taşınmazlar, iştirak hisseleri, kurucu senetleri ve intifa senetleri ile rüçhan haklarının satışındaki sürelerin hesabında, devir olunan veya bölünen kurumda geçen süreler de dikkate alınır.

f) Menkul kıymet veya taşınmaz ticareti ve kiralanmasıyla uğraşan mükelleflerin bu amaçla ellerinde bulundurdukları değerlerin satışından elde ettikleri kazançlar istisna kapsamı dışındadır.

Yapılan düzenlemeler ile elde tutma süresine bağlı olarak değişken bir kazanç tespiti yoluna gidilmekte olup, aşağıdaki sürelerde elde etmeye bağlı olarak doğan kazancın ilgili süreye isabet eden kısmı istisna tutulmaktadır.

1) İki tam yıldan sonra satıştan doğan kazançlarda \%40

2) Üç tam yıldan sonra satıştan doğan kazançlarda \%50

3) Dört tam yıldan sonra satıştan doğan kazançlarda \%60 


\section{4) Beş tam yıldan sonra satıştan doğan kazançlarda \%75}

Tasarının genel gerekçesinde, 21. maddede yer alan düzenlemenin amacı, işletmelerin bağı değerlerinin ekonomik faaliyetlerde daha etkin bir şekilde kullanılmasına olanak sağlanması ve işletmelerin mali bünyelerinin güçlendirilmesi şeklinde ifade edilmiştir. Bu maddede belirtilen koşulların sağlanması halinde söz konusu taşınmazlar ve iştirak hisseleri ile kurucu senetleri, intifa senetleri ve rüçhan hakları elde tutulma süresine bağlı olarak istisnadan yararlanılacağı hüküm altına alınmıştır.

İstisnaya konu olan taşınmazlar, Türk Medenî Kanununda yer alan, taşınmaz olarak tanımlanan, esas niteliği bakımından bir yerden başka bir yere taşınması mümkün olmayan, dolayısıyla yerinde sabit olan mallardır. Bunlar Türk Medenî Kanununun 704. maddesinde; arazi, tapu siciline ayrı sayfaya kaydedilen bağımsız ve sürekli haklar, kat mülkiyeti kütüğüne kayıtlı bağımsız bölümler olarak sayılmıştır. Taşınmazların bu istisnaya konu edilebilmesi için Türk Medenî Kanununun 705. maddesi gereğince kurum adına tapuya tescil edilmiş ve aktife alınmış olması ya da ticari kazancını bilanço esasına göre tespit eden gerçek kişiler için tapuya tescil ettirilerek işletme aktifine alınmış olması gerekmektedir.

İstisnanın uygulanabilmesinin temel koşulu, taşınmazlar ve iştirak hisseleri ile kurucu senetleri, intifa senetleri ve rüçhan haklarının belirli bir süreyle aktifte yer almasıdır. Örneğin, en az iki tam yıl aktifte yer alma şartı 730 günün dolmasıyla gerçekleşecektir.

Taşınmaz satış kazancı istisnasından, varlık kiralama şirketleri ile sat geri kirala yönteminde finansal kiralama şirketleri ve bunlara taşınmazlarını devreden ve devralan mükelleflerin süre şartı aranmaksızın yararlanabilmelerine ilişkin düzenleme yapılmıştır.

Bu değerlerin satışından elde edilecek kazancın, istisnadan yararlanan kısmının beş yıl süreyle pasifte özel bir fon hesabında tutulması gereklidir. Söz konusu aktif kalemlerin para karşılığı olmaksızın devir ve temliki, takası gibi işlemler istisna kapsamına girmemektedir. Bu istisna, satışın yapıldığı dönemde uygulanacaktır. Bu nedenle, satışın yapıldığı hesap dönemine ilişkin gelir vergisi beyannamesinin verileceği tarihe kadar, söz konusu satış kazancının özel bir fon hesabına alınması gerekmektedir. Satış bedelinin, satışın yapıldığı yılı izleyen ikinci takvim yılının sonuna kadar tahsil edilmesi şarttır. Bu süre içinde tahsil edilemeyen veya beş yıl içinde özel fon hesabından başka bir hesaba (sermayeye ilave hariç) nakledilen, işletmeden çekilen, dar mükelleflerce ana merkeze aktarılan kazanç kısmı için, uygulanan istisna dolayısıyla zamanında tahakkuk ettirilemeyen vergiler ziyaa uğramış sayılır. Aynı süre içinde işletmenin tasfiyeye girmesi (devir ve bölünmeler hariç) halinde de bu hüküm uygulanacaktır.

İstisna uygulaması esas itibarıyla gerçek kişiler ve kurumlar açısından geçerlidir. Ancak, esas faaliyeti menkul kıymet veya taşınmaz ticareti olan gerçek kişiler ve kurumların bu amaçla, diğer bir ifadeyle ticari faaliyet çerçevesinde iktisap ettikleri ve ellerinde tuttukları kıymetlerin satışından elde ettikleri kazançlar için istisnadan yararlanmaları mümkün değildir. Satışa konu edilen kıymetlerin iki tam yıl işletme 
aktifinde kayıtlı olması da durumu değiştirmeyecektir. Aynı durum, satmak üzere taşınmaz inşaatı ile uğraşan mükellefler açısından da geçerlidir. Ancak, taşınmaz ticareti ile uğraşan mükelleflerin faaliyetlerinin yürütülmesine tahsis ettikleri taşınmazların satışından elde ettikleri kazançlara istisna uygulanabilecek; taşınmaz ticaretine konu edilen ve kiralama veya başka surette değerlendirilen taşınmazların satış kazancı ise istisnaya konu edilmeyecektir.

Taşınmaz ticareti, aynı zamanda söz konusu taşınmazların kiralanmasını da kapsamaktadır. Faaliyet konusu, taşınmazların inşası ve kiraya verilmesi olan işletmelerin bu amaçla inşa ettikleri ve aktiflerinde bulundurdukları taşınmazların satılması neticesinde elde edilen kazançların istisna kapsamında değerlendirilmesi mümkün olmayıp, "...taşınmazların kiralanmasıyla uğraşan işletmelerin..." ifadesi konuya açıklık kazandırmak amacıyla fıkra hükmüne eklenmiştir.

Örneğin, inşaat faaliyetinde bulunan bir işletmenin satın aldığı arsayı iki yıl geçtikten sonra satması halinde ya da faaliyet konusu alışveriş merkezleri inşa etmek ve kiraya vermek olan şirketin bu amaçla inşa ettiği taşınmazları iki yıl geçtikten sonra satması halinde, söz konusu işletmelerin bu istisnadan yararlanması mümkün olmayacaktır.

İstisnanın temel amacı işletmelerin mali yapılarının güçlendirilmesinin teşviki olduğundan, ekonomik açıdan işletmelere ilave imkan sağlamayan işlemler istisna kapsamı dışında kalacaktır.

Ayrıca, taşınmazların kaynak kuruluşlarca kira sertifikası ihracı amacıyla varlık kiralama şirketlerine satışı ile bu varlıkların varlık kiralama şirketlerince taşınmazın devralındığı kuruma satışından doğan kazançlar için oranın \%100 olarak uygulanacağı ve bu taşınmazlar için süre şartı aranmayacağı fıkrada belirtilmiştir. Ancak, söz konusu taşınmazların kaynak kuruluş tarafından veya kaynak kuruluşça kira sözleşmesinden kaynaklanan yükümlülüklerin yerine getirilememesi hali hariç olmak üzere, varlık kiralama şirketi tarafından üçüncü kişi veya kurumlara satılması durumunda, bu varlıkların kaynak kuruluştaki, varlık kiralama şirketine devirden önceki kayıtlı değeri ile anılan kurumlarda ayrılan toplam amortisman tutarı dikkate alınarak satışı gerçekleştirilen kurum nezdinde vergilendirme yapılacaktır. (Gelir Vergisi Kanunu Tasarısı, Genel Gerekçe, http://www2.tbmm.gov.tr/d26/1/1-0516.pdf )

Mevcut yasal düzenleme ile tasarıda yer alan ve yukarıda ayrıntılı bir şekilde açıklanan hükümler incelendiğinde Tablo 1'de görüldüğü üzere;

5520 sayılı Kurumlar Vergisi Kanununda yer alan iki tam yıl elde etme süresine bağlı olarak istisna edilen $\% 75^{\prime}$ lik oran yukarıdaki yer alan oranlar ve sürelerle değiştirilmektedir.

Ayrıca Gelir Vergisi kanun tasarısında istisnanın, sat geri kirala yönteminde finansal kiralama şirketleri ve bunlara taşınmazlarını devreden ve devralan mükelleflerin, süre koşulu sınırı olmaksızın yararlanabilecekleri hüküm altına alınmıştır. (Erkan Çelik, Yeni Gelir Vergisi Kanunu Tasarısına Göre Gayrimenkul ve İştirak Hisse Satışlarında İstisnalar, http://www.verginet.net/dtt/1/Yeni-Gelir-Vergisi-KanunuTasarisi-Gayrimenkul-Istirak-Hisse -Satislari-Istisnalar.aspx) 
Tablo 1: Taşınmazların Elden Çıkarılmasında 5520 sayılı Kurumlar Vergisi Kanunu ile Tasarı Arasındaki Farklılıklar

\begin{tabular}{|l|l|}
\hline \multicolumn{1}{|c|}{ MEVCUT DURUM (K.V.K. 5 / 1 (e) } & \multicolumn{1}{|c|}{ TASARı (md. 21) } \\
\hline Kurumların....... & $\begin{array}{l}\text { Ticari kazancını bilanço esasına göre } \\
\text { tespit eden gerçek kişiler ile kurumların } \\
\ldots .\end{array}$ \\
\hline $\begin{array}{l}\text {...en az iki tam yıl süreyle aktiflerinde } \\
\text { yer alan taşınmazlar ......satışından } \\
\text { doğan kazançların \% 75'lik kısmı }\end{array}$ & $\begin{array}{l}\text { 1) İki tam yıldan sonra ..........\%40 } \\
\text { 2) Üç tam yıldan sonra ..........\%50 } \\
\text { 3) Dört tam yıldan sonra .......\%60 } \\
\text { 4) Beş tam yıldan sonra ........\%75 }\end{array}$ \\
\hline $\begin{array}{l}\text { 5. madde 1. fıkra ve (e) bendi şeklinde } \\
\text { düzenlenmiş }\end{array}$ & $\begin{array}{l}\text { Mevcut düzenlemede yer alan 1. fıkra (e) } \\
\text { bendi içinde yer alan ifadeler ayrı ayrı } \\
\text { bentlerde düzenlenmiş }\end{array}$ \\
\hline
\end{tabular}

Diğer gerçek kişiler açısından ise, Tasarının 45, 46, 47, 48 ve 49. maddelerinde düzenlemeler yer almaktadır. Bu düzenlemeler tasarıda şu şekilde yer almıştır.

\subsection{Değer Artış Kazançları}

MADDE 45- "(1) Aşağıda yazılı mal ve hakların elden çıkarılmasından doğan kazançlar, değer artış kazancıdır:

a) Ivazsız olarak iktisap edilenler hariç olmak üzere, 37 nci maddenin birinci fıkrasının (a), (b), (c), (d), (f) ve (ğ) bentlerinde yazılı mal (gerçek usulde vergiye tabi çiftçilerin zirai üretimde kullandıkları taşınmazlar dâhil) ve haklar ile (g) bendinde belirtilen motorlu yükleme ve boşaltma araçları ile motorlu taşıtların hat, plaka veya işletme haklarının elden çıkarılmasından doğan kazançlar (Kooperatiflerin ortaklarına bu sıfatlan dolayısıyla tahsis ettikleri taşınmazları tahsis tarihinde ortak tarafından satın alınmış sayılır.).

(2) Bu maddede geçen elden çıkarma ibaresi, yukarıda yazılı mal ve hakların her ne suretle olursa olsun satılmasını, bir bedel karşılığında devir ve temlikini, trampa edilmesini, takasını, kamulaştırılmasını, devletleştirilmesini ve ticaret şirketlerine sermaye olarak konulmasını ifade eder.

(3) Ticari bir işletmenin envanterinde kayıtlı bulunmaması kaydıyla, kat karşıığı inşaat işleri dâhil sahip olunan arsa üzerine inşaat yapan veya yaptıranların bu işlere tahsis ettikleri arsa veya arsa payları da, inşaat faaliyetinin ticari mahiyette olup olmadığına bakılmaksızın, elden çıkarılmış sayılır."

Tasarının 45. maddesi değer artış kazançlarının hangi mal ve hakların elden çıkarılması halinde doğacağını düzenlemektedir. Buna göre elden çıkarılması halinde 
değer artışı kazancını oluşturan Gelir Vergisi Kanununun mükerrer 80. maddesindeki unsurlar tasarıda aynen korunmuştur. Ayrıca mevcut kanunda değer artışına konu unsurların belirlendiği bentlerin içinde bu kıymetlerin elde edilme sürelerine bağlı istisnalar da aynı metin içinde düzenlenmişken; tasarıda istisnalar ayrı bir madde halinde düzenlenmiştir.

45. maddenin 1. fıkrasının (a) bendinde mevcut yapı korunmuş ayrıca "Motorlu taşıma, çekme, yükleme ve boşaltma araçları, her türlü motorlu araç, makine ve tesisat ile bunların eklentileri (bunlara ait hat ve plakalar ile işletme hakları dahil)" elden çıkarılmasından sağlanan kazançlar da vergi kapsamına alınmıştır. Yine anılan maddenin 2. fıkrasındaki elden çıkarma deyimi "birinci fıkrada belirtilen mal ve hakların her ne suretle olursa olsun satılmasını, bir bedel karşılığında devir ve temlikini, trampa edilmesini, takasını, kamulaştırılmasını, devletleştirilmesini ve ticaret şirketlerine sermaye olarak konulmasını ifade eder." hükmü mevcut düzenlemede yer alan şekliyle kalmıştır.

Bu maddeyle ilgili olarak belirtilmesi gereken diğer önemli bir nokta ise; maddenin 3. fıkrasıdır. Bu fıkrada "Ticari bir işletmenin envanterinde kayıtı bulunmaması kaydıyla, kat karşılığı inşaat işleri dahil sahip olunan arsa üzerine inşaat yapan veya yaptıranların bu işlere tahsis ettikleri arsa veya arsa payları da, inşaat faaliyetinin ticari mahiyette olup olmadığına bakılmaksızın, elden çıkarılmış sayılır." hükmü yer almaktadır. Buna ilişkin gerekçede aşağıdaki açıklama yapılmıştır.

“Üçüncü fıkrada, kentleşme ile birlikte değeri yükselen arsaların satılması veya bu arsaların üzerine bina inşa edilmesi durumunda elde edilecek kazançların kayıt altına alınarak vergilendirilmesi öngörülmektedir. Bu itibarla, ticari bir işletmenin envanterinde kayıtlı olmaması şartıyla, sahip olunan arsa üzerine inşaat yapan veya yaptıranların (kat karşılığı inşaat işleri dahil) bu işlere tahsis ettikleri arsa veya arsa paylarının da tahsis tarihi itibarıyla elden çıkarılmış sayılacağı” öngörülmektedir. İlgili düzenleme dikkate alındığında arsanın tahsis tarihi itibariyle karşılığında tahsil edilen bir gelir olmasa bile vergi alınacağı gibi bir sonuç çıkmaktadır. Ancak "Özel İnşaatlarda Değer Artış Kazancının Tespiti” başlıklı 48. maddede yer alan düzenlemeler buna izin vermemektedir. Şöyle ki; tasarının 48/2 maddesinde "..elden çıkarılan arsa veya arsa paylarından doğduğu kabul edilen elden çıkarma kazançları, inşa edilen taşınmazların satıldığı tarihler itibarıyla ve satılan taşınmaza isabet eden arsa payıyla sınırlı olarak gerçekleşmiş sayılır. Bu satışlar nedeniyle yapılan tahsilatların, öncelikle satılan taşınmaza isabet eden arsa veya arsa payının elden çıkarma bedeline ilişkin olduğu kabul edilir." hükmü yer almaktadır. (Yeni Gelir Vergisi Tasarısı Raporu, Mazars Denge, http://www.mazars.com.tr/Anasayfa/Haberler/Rapor-Arastirmalar/Yeni-Gelir-Vergisi Kanunu-Tasarisi, s.23-24) Tasarının özel inşaat işleri ile ilgili 45. maddenin 3. fıkrası ile özel inşaat işlerinde değer artış kazancının tespitine ilişkin hükümler içeren 48. maddesi özel mevcut yasada bulunmayan düzenlemeler içermektedir. Özellikle anılan bu iki madde, tasarının kentsel rantları vergilendirme amacına yönelik düzenlemeleridir. Ancak “özel inşaatlarda değer artış kazancının tespiti” başlıklı 48. maddenin daha basit, anlaşılır bir şekilde düzenlenmesinde yarar görülmektedir. 


\subsection{Safi Değer Artış Kazancı}

MADDE 47- "(1) Safi kazanç, elden çıkarma karşılığında alman para ve ayınlarla sağlanan ve parayla temsil edilebilen her türlü menfaatlerin toplamından, elden çıkarılan mal ve hakların maliyet bedelleri ile elden çıkarma dolayısıyla yapılan ve satıcının uhdesinde kalan giderlerin ve ödenen vergi ve harçların indirilmesi suretiyle bulunur.

(2) Hasılatın ayın ve menfaat olarak sağlanan kısmının tutarı, Vergi Usul Kanununun değerleme hükümlerine göre belirlenir.

(3) Maliyet bedelinin mükelleflerce tespit edilememesi halinde maliyet bedeli yerine, Vergi Usul Kanunu hükümlerine göre, takdir komisyonlarınca tespit edilecek bedel, kazancı bilanço veya işletme hesabı esasına göre tespit edilen işletmelerde ise son bilançoda veya envanter kayıtlarında gösterilen değer esas alınır.

(4) Faaliyeti durdurulan ticari veya zirai bir işletmeye ait envanter kayıtlarında yer alan amortismana tabi iktisadi kıymetlerin elden çıkarılması halinde, iktisadi kıymetlerin maliyet bedeli yerine, kayıtlara göre amortismanlar düşüldükten sonra kalan net değeri esas alınır. Durdurulan serbest meslek faaliyetine ait envanter kayıtlarında yer alan amortismana tabi iktisadi kıymetlerin elden çıkarılması halinde de aynı esaslar uygulanır.

(6) Mal ve hakların elden çıkarılmasında iktisap veya maliyet bedeli, elden çıkarılan mal ve hakların, elden çıkarıldığı ay hariç olmak üzere Türkiye istatistik Kurumunca belirlenen üretici fiyatları endeksindeki artış oranında artırılarak tespit edilir."

Tasarıda yer alan 47. madde incelendiğinde; değer artışında vergiye tabi tutulacak safi kazancın tespitine ilişkin hükümlerin yer aldığı görülmektedir. Buna göre safi kazanç mevcut düzenlemede de yer aldığı şekliyle elde edilen hasılattan bu hasılatın elde edilmesi için katlanılan maliyet, gider ve vergilerin düşülmesi suretiyle bulunmaktadır. Ayrıca ilgili maddede hasılatın, elden çıkarma karşıı̆ında alınan para veya mal ve hizmet şeklinde sağlanan, para ile temsil edilebilen her türlü menfaatlerin toplamından oluştuğu, bu tutardan düşülecek olan unsurların ise, elden çıkarılan mal ve hakların maliyet bedelleri ile elden çıkarma dolayısıyla yapılan ve satıcı tarafından yüklenilen giderler, ödenen vergi ve harçlar olduğu ifade edilmiştir. Elde edilen karşııı̆ın para dışında mal ya da menfaat olması halinde Vergi Usul Kanununun değerleme ile ilgili hükümleri uygulanacağı, mal ve hakların maliyet bedelinin mükelleflerce tespit edilememesi durumunda maliyet bedeli yerine; Vergi Usul Kanunu hükümlerine göre, takdir komisyonlarınca tespit edilecek bedelin, kazancı bilanço veya işletme hesabı esasına göre tespit edilen işletmelerde ise, son bilançoda ya da envanter kayıtlarında gösterilen değerin esas alınacağı 193 sayılı Gelir Vergisi Kanunu hükümleri değiştirilmeden aynen alınmıştır. (Gelir Vergisi Kanunu Tasarısı, Genel Gerekçe, http://www2.tbmm.gov.tr/d26/1/1-0516.pdf )

Safi değer artış kazancının tespitine ilişkin olarak tasarı ile mevcut yasal düzenleme arasındaki taşınmazları ilgilendiren farklııklardan biri 193 sayılı Gelir Vergisi Kanununda değer artış kazancının tespiti için endeksleme yapabilmek için Üretici Fiyat Endeksi (ÜFE) artış oranının \%10 ve üzerinde olması şartının tasarıda kaldırıımış 
olmasıdır. ÜFE endeksindeki artış oranı ne olursa olsun maliyet artırımı yapılabilecektir. Bir diğer önemli farklılık ise mevcut düzenlemede mal ve hakların elden çıkarılmasında sadece "iktisap bedeli" ifadesi yer alırken, tasarıda "iktisap bedeli veya maliyet bedeli" ifadesinin yer almasıdır.

Vergilendirilmeyecek değer artışları açısından bakıldığında; 193 sayılı Gelir Vergisi Kanununun 81. maddesinin (1), (2) ve (3) fıkralarında düzenlenen hükümlerin tasarıda da aynen korunduğu fakat tasarıda bu hükümlerin fıkralarda eğil bentlerde düzenlendiği görülmektedir.

\section{3. Özel İnşaatlarda Değer Artış Kazancının Tespiti}

MADDE 48-"(1) 45 inci maddenin üçüncü fıkrası kapsamına giren hallerde;

a) Kat karşılığı inşaat işleri dolayısıyla arsa sahibinin uhdesinde kalan arsa payının tahsis tarihindeki emsal bedeli, inşaat işine tahsis edilen arsa payının elden çıkarma bedeli olarak kabul edilir,

b) Müteahhit tarafından arsa sahibine teslim edilen taşınmazların maliyet bedeli üzerinden arsa sahibine fatura edilen tutar ise müteahhide devredilen arsa payının elden çıkarma bedeli olarak kabul edilir,

c) Kat karşılığı inşaat söz konusu olmaksızın arsa sahibi tarafından yapılan veya yaptırılan diğer inşaat işlerinde, inşaata tahsis edilen arsanın tahsis tarihindeki emsal bedeli, bu arsanın elden çıkarma bedeli sayılır.

(2) Yukarıdaki fıkraya göre elden çıkarılan arsa veya arsa paylarından doğduğu kabul edilen elden çıkarma kazançları, inşa edilen taşınmazların satıldığı tarihler itibarıyla ve satılan taşınmaza isabet eden arsa payıyla sınırlı olarak gerçekleşmiş sayılır. Bu satışlar nedeniyle yapılan tahsilatların, öncelikle satılan taşınmaza isabet eden arsa veya arsa payının elden çıkarma bedeline ilişkin olduğu kabul edilir.

(3) Kat karşılığı inşaat işleri de dâhil olmak üzere, sahip olduğu arsa üzerine inşaat yapan veya yaptıranların inşaat veya satış faaliyetlerinin 14 üncü maddeye göre ticari faaliyet olarak kabul edilmediği hallerde (aynı maddenin beşinci fıkrası hükmü hariç), bu kapsamda edinilen taşınmazlar arsa sahibi yönünden inşaatın bitim tarihi itibarıyla ilk defa iktisap edilmiş sayılır. Inşaatın bitim tarihi yapı kullanma izin belgesinin alındığı tarihtir. Ancak taşınmazın veya taşınmazların yapı kullanma izin belgesi alınmadan önce fiilen kullanılması halinde, bunların kullanıma başlanma tarihine itibar edilir.

(4) Üçüncü fıkraya göre arsa sahibi tarafından ilk defa iktisap edildiği kabul edilen taşınmazların maliyet bedeli, kat karşılığı inşaat söz konusu olmaksızın inşa edilen ya da ettirilen taşınmazlarda, inşaata tahsis edilen arsanın emsal bedeli ile arsa sahibinin fiili inşaat maliyetlerinin toplamından ibarettir. Kat karşılığı inşaat işleri kapsamında iktisap edilen taşınmazlarda ise maliyet bedeli, arsa sahibinin uhdesinde kalan arsa payının emsal bedeli ile müteahhit tarafından 15 inci maddenin ikinci fıkrasına göre hesaplanan tutardan oluşur. 
(5) Bu madde kapsamında doğan değer artış kazancında zamanaşımı, inşa edilen taşınmazların satıldığı tarihler itibarıyla ve satılan taşınmaza isabet eden arsa payıyla sınırı olmak üzere taşınmazın satıldığı tarihten sonraki takvim yılının başından başlar."

Tasarının 48. maddesi kentleşmeyle birlikte yaygın bir uygulama haline gelen özel inşaat işlerinde (kat karşıı̆ı̆ı inşaat işleri dâhil) değer artış kazancının tespitine ilişkin özellik arz eden hususlar düzenlemektedir.

Ticari mahiyette olmayan özel inşaat işleri dolayısıyla elde edilen değer artış kazancı iki şekilde ortaya çıkmaktadır. Birincisi, arsa sahibinin uhdesinde bulunan arsa payının elden çıkartılması sonucu doğan bir değer artış kazancı; ikincisi ise, inşaat işini arsa sahibinin kendisinin yapması veya kat karşılığı yaptırması dolayısıyla elde etmiş olduğu taşınmazların satışı sonucu ortaya çıkan değer artış kazancıdır. Bahsi geçen iki farklı değer artış kazancının tespitinin sağıkklı bir şekilde yapılabilmesi için, madde metninde arsa veya arsa payına ilişkin maliyet bedeli ile taşınmazlara ilişkin maliyet bedelinin hesaplanmasına ilişkin açıklamalar yapılmıştır.(Gelir Vergisi Kanunu Tasarısı, Genel Gerekçe, http://www2.tbmm.gov.tr/d26/1/1-0516.pdf )

\subsection{Değer Artış Kazançlarında İstisnalar}

MADDE 49-"(1) Aşağıda yazılı değer artış kazançları gelir vergisinden müstesnadır:

a) ikamet amacıyla satın alınan ve fiilen ikamet edilen tek konutun elden çıkarılmasından doğan kazançlar (Bu istisnaya arsa payının devri sonucu tek konut alan arsa sahiplerinin, arsa payının devri sonucu doğan değer artış kazançları da dâhil olup bu bendin uygulanmasında mükellef ile eş ve çocuklar birlikte dikkate alınır.).

b) 37 nci maddenin birinci fıkrasının (a), (b) (c) ve (f) bentlerinde yazılı olan mal (motorlu yükleme ve boşaltma araçları ile gerçek usulde vergiye tabi çiftçilerin zirai üretimde kullandıkları taşınmazlar dâhil) ve haklar ile tam mükellef kurumlara ait olan pay senetlerinin, ortaklık haklarının veya hisselerinin elden çıkarılmasında (Bu bendin uygulanmasında, kooperatiflerin ortaklarına tahsis ettikleri taşınmazlar tahsis tarihinde; finansal kiralama yoluyla iktisap edilmiş taşınmazlar ise finansal kiralama sözleşmesinin imzalandığı tarihte iktisap edilmiş sayılır. Arsaya karşılık iktisap edilen bina veya bağımsız bölümlerde ise iktisap tarihi olarak, 14 üncü maddenin beşinci fıkrası hükmü hariç, 15 inci maddenin birinci fıkrasında belirtilen tarihe itibar edilir.);

1) Iki tam yıldan fazla süreyle elde tutulanlardan elde edilen gelirlerin \%40',,

2) Üç tam yıldan fazla süreyle elde tutulanlardan elde edilen gelirlerin \%50'si,

3) Dört tam yıldan fazla süreyle elde tutulanlardan elde edilen gelirlerin \%60'ı,

4) Beş tam yıldan fazla süreyle elde tutulanlardan elde edilen gelirlerin \%75'i."

Gelir Vergisi Kanunu Tasarısının 48. maddesinde, sosyal politikalar ve ekonomik teşvikler nedeniyle vergiden müstesna tutulan değer artış kazançlarına yer verilmektedir. 
Birinci fıkranın (a) bendinde, ikamet amacıyla satın alınan ve fiilen ikamet edilen tek konutun elden çıkarılmasından doğan kazançlar vergiden istisna edilmektedir. Yine, arsa payının devri sonucu tek konut alan arsa sahiplerinin, arsa payının devri, sonucu ortaya çıkan kazançları vergiden istisna edilmektedir. Bu bendin uygulanmasında istisnadan yararlanacak mükellef ile eş ve çocukları birlikte dikkate alınacaktır. Bu istisna, bir ailenin ikamet amacıyla satın aldığı ya da kat karşılığı teslim aldığı konutu vergisiz olarak elden çıkarmalarına olanak sağlamaktadır. (1). fıkranın (a) bendinde yer alan bu düzenleme yeni bir istisna niteliğindedir.

(b)bendinde ise tasarının 45. maddesi kapsamında değer artış kazançlarını oluşturan unsurların elden çıkarılmasından sağlanan kazançlara elde tutulma süresine bağlı olarak değişen oranlarda istisna uygulaması getirilmektedir. Ayrıca istisna uygulaması açısından iktisap tarihi önem arz ettiğinden, kooperatiflerin ortaklarına bu sıfatları dolayısıyla tahsis ettikleri taşınmazların tahsis tarihinde; finansal kiralama yoluyla iktisap edilmiş taşınmazların ise finansal kiralama sözleşmesinin imzalandığı tarihte iktisap edilmiş sayılacağı öngörülmektedir. (Gelir Vergisi Kanunu Tasarısı, Genel Gerekçe, http://www2.tbmm.gov.tr /d26/1/1-0516.pdf )Sonuç olarak 48. madde ile ilgili olarak değer artış kazançlarının istisnasında, tek konutu olan ve ikamet amaçlı kullanılanlarda tam istisna uygulaması ve elde etme süresine göre değişken oranlı istisna uygulaması dikkat çekmektedir.

\section{Sonuç}

Şahsi servetin bir parçası olan taşınmazların satışından elde edilen gelire ilişkin Gelir Vergisi Kanunu Tasarısının öngördüğü düzenleme mevcut düzenlemeye göre özellikle istisna uygulamasına ilişkin maddelerde önemli ölçüde farklılık getirmektedir. Buna göre; tasarının genel amaçlarından biri olan vergi tabanının genişletilmesine yönelik olarak kentsel rantların vergilendirilmesindeki istisnaların daraltıldığı görülmektedir. Bu amaç doğrultusunda da mevcut düzenlemede yer alan ve 5 yıldan sonra uygulanan \%100'lük istisna kaldırılmaktadır. Onun yerine taşınmazın elden çıkarılma süresine göre \%40 ila \%75 arasında değişen kademeli istisna getirilmektedir. Tasarı da ayrıca sosyal politikalarla uyumlu düzenlemeler kapsamında ikamet amacıyla satın alınan ve fiilen ikamet edilen tek konutun elden çıkarılmasından doğan gelirlere de istisna getirilmektedir. Bu istisna tasarının en önemli yeniliklerinden biri olup, ikamet amaçlı konut alım satımında kayıt dışılığa neden olan tapu harcını düşük ödemek ve/veya değer artış kazancı vergisini ise hiç ödememek sorununu da azda olsa ortadan kaldırabilecek nitelikte olumlu bir düzenlemedir.

Tasarıda bir diğer dikkate alınması gereken husus ise enflasyon düzeltmesidir. Tasarıda mevcut düzenlemenin aksine fiyat enflasyonunun çift haneli rakama ulaşıp ulaşmadığına bakıımaksızın değer artış kazancının tespitinde enflasyondan arındırma kabul edilmiştir. Bu düzenlemenin mükellefler açısından oldukça olumlu olduğu söylenebilir.

Elde tutulan yıla göre artan istisna uygulaması mevcut düzenlemeye göre daha ileri bir düzenleme gibi görülmektedir. Ancak bu düzenlemenin gerçekten fayda sağlaması için taşınmazın gerçek iktisap ve satış bedelinin bilinmesi gerekmektedir. 
Çünkü taşınmazın elden çıkarılmasından elde edilen kazancın vergilendirilmesinde taşınmazın gerçek iktisap ve satış bedelinin tespiti büyük önem taşımaktadır. Günümüzde mevcut düzenlemelerde yaşanan sorunların başında taşınmazın gerçek değerinin ve değer artış kazancının doğru bir şekilde tespit edilememesi gelmektedir. $\mathrm{Bu}$ sorunun çözümüne ilişkin olarak mevcut vergi kanunlarımızda bir otokontrol müessesi de yer almamakta, taşınmazın gerçek satış ve iktisap bedellerinin tespitine ilişkin denetimin ise etkin bir şekilde yapılamadığı bilinmektedir.

Gelir Vergisi Kanunu Tasarısında da ifade edildiği üzere gerek taşınmazlardaki değer artışının gerekse bunlar üzerinden elde edilen kira vb. gelirlerin vergilendirilmesi ve bu suretle bunlardan elde edilen rantların kamuya aktarılması bir zorunluluk olarak ortaya çıkmaktadır. Ancak mevcut 193 sayılı Gelir Vergisi Kanunu kapsamındaki düzenlemelerde değer artış kazançlarının gerçekçi ve doğru bir şekilde tespiti ve taşınmaz değer artışlarının kamuya aktarılmasında etkin bir düzenleme ve kontrol mekanizması bulunmamaktadır. Bu husus tasarı ile düzeltilmeye çalışıııor gibi görülse de tasarıda sadece istisna uygulamasının daraltıldığı görülmektedir. Sorun istisna uygulamasından çok safi değer artış kazancının hesabında esas alınan iktisap bedelinin ve dolayısıyla satış bedelinin mükellef tarafından doğru bir şekilde bildirilmemesi ve tapu işlemlerinin gerçek değeri üzerinden yapılmamasıdır.

Dolayısıyla tasarının da, mevcut uygulamada olduğu gibi taşınmazın gerçek değerini ve değer artışlarını vergilendirmeye yönelik düzenlemeler içermediği söylenebilir. Bununla birlikte taşınmazın gerçek değerinin tespitine yönelik bir otokontrol mekanizmasının olmaması ve taşınmazların güncel değerlerini kayıt altına alacak bir veri tabanının bulunmaması gibi faktörler nedeniyle vergi tabanının genişletilmesi amacı çok gerçekçi olmayacaktır.

Günümüzde vergi idaresi de bu sorunun bilincinde olup, taşınmazların gerçek değeri üzerinden tapu işlemlerinin yapılması hususunda halkı bilinçlendirici bilgilendirmeler yapmaktadır. ${ }^{15}$ Ancak bu bilgilendirmeler ile birlikte yasal mevzuat anlamında bir takım düzenlemelerin yapılması daha uygun olacaktır. Bu düzenlemelerden ilki vergi konseyinin yapmış olduğu bir çalışmada şu şekilde ortaya konmuştur.

"Tapu işlemleri ile ilgili olarak yaşanan sorunlardan biri tapu işlemleri yaptırılırken taşınmazların alım satım değerinin her zaman doğru bildirilmemesidir.

Yaşanan bu sorunun çözüme kavuşturulması için; belli nitelikleri haiz gayrimenkullerin değerleme işlemlerinin gayrimenkul değerleme şirketlerine yaptırılması zorunluluğu getirilmesi; tapu işlemine konu olan gayrimenkul alım satım bedellerinin ise bankacılık sistemi kullanılarak hak sahiplerine aktarılması önerilmektedir.

Gayrimenkul değerlemesine ilişkin olarak, farklı bölgelerdeki (büyükşsehir belediye sınırları dahilinde bulunup bulunmaması vb.) ve farklı nitelikteki (bina, arsa, arazi vb.) gayrimenkuller için ayrı ayrı belirlenecek hadler dahilinde, mevcut

\footnotetext{
15 Konu hakkında hazırlanan broşür, afiş ve soru/cevaplara http://www.gib.gov.tr/tapu-islemlerindegercek-degerin-beyani adresinden ulaşabilirsiniz.
} 
gayrimenkul değerleme şirketlerine ve lisanslı gayrimenkul değerleme uzmanlarına değerleme yaptırılması zorunluluğu getirilmesi önerilmektedir. Değerleme neticesinde tespit edilen tutarlar tapu işlemlerinde tapu harcına ve emlak vergisine esas asgari bedeller olarak kabul edilmelidir. Belirlenecek hadlerin altında kalan gayrimenkuller, sistemin etkinliğini azaltmaması ve küçük mülkiyet sahiplerini ilave külfet altına sokmamak için kapsam dışında bırakılmalıdır. Önerilen sistemler hem tapu işlemlerinde beyan edilen alım satım değerlerinin gayrimenkulün gerçek değeri nispetinde olmasını sağlamakta hem de tapu dairelerinde taraflar arasında yaşanan güvensizlik ve tedirginliği önleyecektir. Yüksek tutarda nakit taşımanın oluşturduğu güvenlik riski ise tamamıla bertaraf edilmiş olacaktır."(TBB, 2011: 55)

Gerçekten de 2000'li yılların başından itibaren uygulamaya konulan taşınmaz değerleme şirketleri ve değerleme uzmanlığına yönelik düzenlemeler ile kamuoyunda "Mortgage" olarak bilinen konut finansman sistemine ilişkin yasal düzenlemelerden taşınmaz değer tespit sürecinde yararlanılması oldukça önemlidir. Çünkü günümüzde taşınmazların alım satım sürecinde özellikle tapu işlemleri sırasında taşınmazın gerçek değerini bildirecek mekanizma yer almamaktadır. Mevcut düzenlemede tapu harçlarına ilişkin olarak "taşınmaz devir ve iktisaplarında tapu harcı emlak vergisi değerinden az olmamak üzere beyan edilen devir ve iktisap bedeli üzerinden hesaplanır. Tapuda yapılan işlemden sonra emlak vergisi değerinden daha düşük bir bedel üzerinden harç ödendiğinin veya beyan edilen devir ve iktisap bedelinin gerçek durumu yansıtmadığının tespit edilmesi halinde aradaki farka isabet eden harç ikamalen veya re'sen tarh edilir. Bu suretle tarh edilecek tapu harcı için 213 sayılı Vergi Usul Hukuku'nda yer alan vergi ziyaı cezası yüzde 25 nispetinde uygulanır" hükmü yer almıştır.

İlgili hükümde de görüldüğü üzere tapu harcının, emlak vergisi değerinden az olmamak üzere beyan edilen devir ve iktisap bedelinden, devir ve iktisap bedelinin gerçek durumu yansıtmadığının tespitinde ise aradaki farkın ikmalen ve re'sen tarh edilerek belirlenecek değer üzerinden ödeneceği öngörülmektedir. Ancak mükellefleri taşınmazın gerçek değeri beyana teşvik edici bir unsur ve vergi güvenlik önlemi yapılan düzenlemede yer almamakta hatta mükellefler emlak vergisine esas vergi değerinden tapu harcı ödemeye teşvik edilmektedir. Taşınmazların herhangi bir sebeple devir ve intikallerinde tapu harcına esas değerin daha az harç ödenmesi amacıyla, alt sınır olan emlak vergisine esas değerden ödenmesi ileride oluşabilecek değer artış kazançlarının vergilendirilmesi anlamında da oldukça önemlidir. Mevcut düzenlemede yer alan 5 yıldan sonra uygulanan \% 100 'lük istisna kaldırılarak yerine getirilen kademeli istisna uygulamasının da amacına ulaşabilmesi için bu konu oldukça önemlidir. Bu açıdan mükelleflerin tapu işlemlerinde taşınmaz değerlerinin alım-satıma konu değeri üzerinden alıcı ve satıcı tarafından binde 20 olarak ödenen harç oranının düşürülmesi hatta kaldırılması düşünülebilir. Böylelikle ülkemizde çoğunlukla alıcı tarafından ödenen ve taşınmazın alım ve satımı sırasında bir maliyet oluşturan tapu harcı oranının düşürülmesi veya kaldırılması taşınmazın tapuda kayıtlı değerini gerçek alım-satım değerine yaklaştırabilecektir. Tasarının geneli üzerinde Çelik (Çelik, http://www.verginet.net) tarafından da ifade edilen bir diğer eksiklik ise önceki düzenlemelerde olduğu gibi, tasarının kanunlaşmasından önce iktisap edilen gayrimenkullerin elden çıkarılmasından doğan kazançların eski düzenlemelere tabi olup 
olmayacağı konusudur. Bu konunun da açıklık kazanması mükellefler açısından oldukça önemlidir.

Tasarının kendi arsası veya başkasının arsası üzerine ticari kazanç kapsamında özel inşaat işleri yapanlara ilişkin, mevcut düzenlemede yer almayan maddeleri ortaya çıkan / çıkabilecek rantın vergilendirilmesi açısından olumludur. Hatta tasarının kentsel rantların vergilendirilmesi amacına yönelik esas düzenlemesinin bu olduğu söylenebilir. Ancak özel inşaatlarda değer artış kazancının tespitini içeren tasarının 48. maddesinin oldukça karışık ve anlaşıımaz olmasından dolayı olarak ileriki dönemlerde ek düzenleme yapılması gereği doğabilir.

Tasarı gerekçede ifade edildiği üzere basit, sade ve kolay anlaşılabilir bir yapıda hazırlanmamıştır. Bunun en önemli nedeni ise madde sayısının mevcut düzenlemelere göre azaltılmış olması fakat fıkra ve bent sayısının artmış olmasıdır. Tasarıda olumlu olan bir yön ise tasarının 26083 sayı ve 17.02.2006 tarihli Resmi Gazete'de yayımlanan "Mevzuat Hazırlama Usul ve Esasları Hakkında Yönetmelik" hükümlerine uygun olarak hazırlanmasıdır. Sonuç olarak tasarının taşınmazlar ile ilgili hükümleri incelendiğinde bu hükümlerin özü itibariyle tasarının genel gerekçesindeki amaçlara uygun yapısal bir durumu yansıttığı söylenemez.

\section{Kaynakça}

Alptürk E. (2007). Gayrimenkul Değerleme Rehberi. Ankara: Maliye ve Hukuk Yayınları.

Açlar A. \& Çağdaş V. (2002). Taşınmaz (Gayrimenkul) Değerlemesi. Ankara: TMMOB Harita ve Kadastro Mühendisleri Odası.

Aytekin S. (2007). "Gayrimenkul Kavramı ve Gayrimenkullerin Kiralanmasında KDV Uygulaması", Mali Çözüm , Sayı:80.

Aslan M. (2014)“Kentsel Rantların Vergilendirilmesi”. Ankara Barosu Dergisi, No:3.

Bulutoğlu K. (1979) Türk Vergi Sistemi. Cilt:2, Altıncı Basılış, Ankara.

Çelik E. (2016) Yeni Gelir Vergisi Kanunu Tasarısına Göre Gayrimenkul ve İştirak Hisse Satışlarında İstisnalar, http://www.verginet.net/dtt/1/Yeni-Gelir-VergisiKanunu-Tasarisi-Gayrimenkul-Istirak-Hisse-Satislari-Istisnalar.aspx Erişim: 15.01.2016.

Gelir İdaresi Başkanlığı (2014). Gayrimenkullerin Elden Çıkarılmasında Vergisel Yükümlülükler Rehberi, 2014, http://www.gib.gov.tr/sites/default/files/ fileadmin/beyannamerehberi/2014gayrimenkul.pdf Erişim: 15.01.2016.

Gayrimenkul Değerlemesi,(2004). İngilizceden Çeviren: Erbil Töre. On ikinci Baskı, Yayın No: 4487, 2004, İstanbul: Appraisal Institute ve IMKB, İstanbul Üniversitesi.

Gelir Vergisi Kanunu Tasarısı, (2016). Genel Gerekçe, http://www2.tbmm.gov.tr/ d26/1/1-0516.pdf Erişim:15.01.2016. 
Kabataş Y. (2005). Gayrimenkul Değerlemesi ve Raporlaması, Yayınlanmamış Doktora Tezi, Marmara Üniversitesi, Sosyal Bilimler Enstitüsü.

Kaya F. (2006). Gayrimenkul Rantlarının Vergilendirilmesi, http://www.vmhk.org.tr/ gayrimenkul-rantların-vergilendirilmesi/ Erişim: 15.05.2016.

TBB (2011).Kayıtlı Ekonominin Geliştirilmesi Sürecinde Kartlı Ödeme Sistemleri ile Yeni Yöntem ve Teknolojiler, Nisan., Yayın No:274, İstanbul: Vergi Konseyi.

Kızılot, Ş., Sarısu, E., Özen, S. \& Kızılot, Z. (2005) Gayrimenkul Rehberi. Ankara: Yaklaşım Yayıncılık.

Nadaroğlu H. (1998). Kamu Maliyesi Teorisi, 10. Baskı. İstanbul: Beta Yayınları.

Özdamar M. (2006) "Ticaret Şirketlerine Sermaye Olarak Taşınmazların Taahhüt Edilmesi”, Gazi Üniversitesi Hukuk Fakültesi Dergisi, Cilt: X, Sayı:1/2.

SPK, (2016). Uluslararası Değerleme Standartları, http://www.spk.gov.tr Erişim: 15.01.2016.

Yeni Gelir Vergisi Kanunu Tasarısı,(2016). http://www.maliye.gov.tr/Lists/Haberler Listesi/Attachments/95/ GVK\%20Sunum.pdf Erişim: 15.01.2016.

Yeni Gelir Vergisi Tasarısı Raporu, (2016). Mazars Denge, http://www.mazars.com.tr/ Anasayfa/Haberler/Rapor-Arastirmalar/Yeni-Gelir-VergisiKanunu-Tasarisi, Erişim: 15.01.2016.

Amme Alacaklarının Tahsil Usulü Hakkında Kanun (6183 S.K.), Resmi Gazete. 8469; 28 Temmuz 1953.

Emlak Vergisi Kanunu (1319 S.K.), Resmi Gazete. 13576; 11 Ağustos 1970.

Gelir Vergisi Kanunu (193 S.K.), Resmi Gazete. 10700; 06 Ocak 1961.

Kurumlar Vergisi Kanunu (5520 S.K.), Resmi Gazete. 26205; 21 Haziran 2006.

Harçlar Kanunu (492 S.K.), Resmi Gazete. 11756; 17 Temmuz 1964.

Türk Medeni Kanunu (4721 S.K.), Resmi Gazete. 24607; 22 Kasım 2001.

Vergi Usul Kanunu (213 S.K.), Resmi Gazete. 11343; 28 Şubat 1963.

Belediye Gelirleri Kanunu (5237 S.K.), Resmi Gazete.6953; 9Temmuz 1948.

Belediye Gelirleri Kanunu (2464 S.K.), Resmi Gazete.17354; 29Mayıs 1981.

Finansman Kanunu (1318 S.K.), Resmi Gazete.13575; 10Ağustos 1970.

Mevzuat Hazırlama Usul ve Esasları Hakkında Yönetmelik Resmi Gazete. 26083; 17 Şubat 2006. 